\title{
Understanding Post-Soviet Ethnic Discrimination and the Effective Use of U.S. Refugee Resettlement: The Case of the Meskhetian Turks of Krasnodar Krai
}

\author{
Steve Swerdlow $\dagger$
}

\section{INTRODUCTION}

Anvar held a bloodied bandage to his forehead and was visibly in pain. Despite his physical discomfort, he spoke with a sense of relief. This was only his second full day in the United States, and he was excited to see family and friends who had made the journey a couple of months before him to this heavily Russian-speaking neighborhood of northeast Philadelphia. Only three weeks earlier, preparing to leave his village of Kholmskaya forever, Anvar set off to pick up his final paycheck. As he walked to his employer's house, five men suddenly rushed him to the ground, kicking and punching him. They set a rabid dog onto him and dragged him inside a nearby house to beat him further. His attackers hurled racial epithets, demanding he "get the hell out of Russia."

Copyright $(2006$ California Law Review, Inc. California Law Review, lnc. (CLR) is a Califomia nonprofit corporation. CLR and the authors are solely responsible for the content of their publications.

$\dagger \quad$ Law clerk to the Honorable Dean D. Pregerson, 2006-2007; J.D., University of Califomia, Berkeley, School of Law (Boalt Hall), 2006; M.1.A., School of Intemational and Public Affairs (SlPA), Columbia University (Harriman Institute), 2003. 1 wish to acknowledge several academic and professional mentors of mine, without whose inspiring examples and careful guidance this work would not have been possible. Among others, these are Peter Juviler, Kate Jastram, Igor Kuznetsov, Alexander Osipov, and Emil Adelkhanov. In addition, the field research presented in this work is the result of countless individuals and human rights activists who were courageous enough to share their stories and insights with me in Russia, Georgia, and the United States. This Comment also benefited from wonderful and careful editing by multiple individuals on the California Law Review, most especially Tina Wong. Finally, 1 dedicate this Comment to my parents, Jay and Andrea Swerdlow, and most of all, my wife, Bhakti Tantod, M.D., for always supporting my passion for human rights and the former Soviet Union. All errors remain my own.

1. Interview with Anvar P., in Philadelphia, Pa. (Dec. 2004) (on file with author); see also Hotline Set Up in Southern Russia to Register Human Rights Violations, (BBC Worldwide Monitoring: InternationaI Reports television broadcast Dec. 10, 2004), available at www. Iexisnexis.com (describing the attack on Anvar). 
When relatives discovered Anvar an hour later, they took him to the hospital. But because of Anvar's illegal status, the doctors refused to treat him. In fact, in the southern Russian region of Krasnodar, Anvar had no legal right to work or drive a car. Even his marriage and the birth of his children were never recognized. His crime, like that of other members of his community who have lived in Krasnodar since fleeing Central Asia in the waning days of the Soviet Union, was simply that the local authorities did not consider him a Russian citizen.

Despite the pain of his wounds, Anvar is visibly at ease on the sofa of his new home in Pennsylvania. One of the first of approximately 15,000 of his fellow brethren to participate in a recently opened refugee resettlement program to the United States, he takes comfort in the fact that he now has official status as a refugee of "special humanitarian concern," and in five years will become an American citizen. ${ }^{3}$

Anvar's people, the Meskhetian Turks, survived a mass deportation from Georgia, interethnic pogroms ${ }^{4}$ in Uzbekistan, and ethnic cleansing in Southern Russia. Their recent resettlement to the United States represents the culmination of a struggle with a Soviet legacy of exile that denied them human rights, ethnic identity, and an ancestral homeland for over six decades. In addition, the choice of this transnational group for resettlement to the United States also reflects the renewal and re-shaping of the longfunctioning and often under-utilized U.S. refugee admissions program in the wake of its near shutdown after September 11, 2001..$^{5}$ At the intersection of human rights law, refugee policy, and area studies, this Comment focuses on the odyssey of the Meskhetian Turks, in an attempt to understand both the current state of minority rights in post-Soviet space and the potentials of U.S. refugee resettlement as a tool for their protection. Drawing on ethnographic fieldwork in Russia, Georgia, and the United States between 2000 and 2005, and over one hundred interviews conducted by the author in the Meskhetian community, this Comment endorses the proposition that an understanding of the case of the Meskhetian Turks provides valuable insights for protecting minority rights in post-Soviet space and effectively using the U.S. refugee admissions program. ${ }^{6}$ It is

2. Immigration and Nationality Act, 8 U.S.C. $\$ 1157(a)(3)(2000)$.

3. Peter Finn, Revival of Cossacks Casts Muslim Group Out of Russia to U.S., WAsh. Post, Nov. 18, 2005, at A19.

4. A pogrom is a massive violent attack, often against members of a minority ethnic or political group. See Pogrom, http://en.wikipedia.org/wiki/Pogrom (last visited Aug. 8, 2006).

5. Barry Newman, In a Riskier World, U.S. Recommits To Aiding Refugees: A Host of Worries Make It Harder To Find and Help Neediest Groups, WALL ST. J., Dec. 11, 2003, at A1.

6. Significant portions of this Comment are derived from field research carried out by the author between 2000 and 2005 under the auspices of various programs. These include the U.S. State Department's Young Leadership Fellows for Public Service (2000-2001, Krasnodar), the Professional Development Fellowship, Institute of International Education (Georgia, May-August 2002), an internship with the International Organization for Migration (1OM) (Krasnodar, July-August 2004), and 
crucial for the legal community to understand the background of a population that comprises one of the largest single admitted refugee groups since September $11 .^{7}$

This Comment also hopes to contribute the experience of the Meskhetian Turks to Congress' consideration of other similarly situated groups in the region. ${ }^{8}$ Indeed, the fate of minorities in the former Soviet Union has decisive consequences for the future of human rights across all of post-Soviet space as well as for American refugee policy in the postSeptember 11 context. Whether it is the persecution of ethnic Russians in Latvia or the violence against Jehovah's Witnesses in Georgia, the problems of minorities occupy center-stage in the difficult transition to civil society underway in the former Soviet Union. While many of these post-Soviet cases have remained outside the mainstream of American refugee policy, the Meskhetian Turks of Krasnodar $\mathrm{Krai}^{9}$ became the beneficiaries of the extraordinarily powerful and extremely selective remedy of resettlement in $2004 .{ }^{10}$ As an organizing principle, this Comment examines the human rights dilemma and Meskhetian Turk resettlement program through the lens of the three classic durable solutions ${ }^{11}$ available to refugees-integration, ${ }^{12}$ repatriation,,$^{13}$ and thirdcountry resettlement ${ }^{14}$ - developed by the United Nations High

trips to Meskhetian communities in the United States made possible by the European Centre for Minority lssues (ECMI) (2004-2005).

7. U.S. Dep't of State et al., Proposed Refugee admissions for fiscal Year 2006: REPORT TO THE CONGRESS (2004), available at http:/www.state.gov/documents/ organization/52475.pdf (manuscript at 32) [hereinafter Proposed RefugeE AdMissions FOR FY 2006] (stating that out of a an estimated total of 14,250 refugees admitted from Europe and Central Asia, "[t]he majority of FY 2005 admissions from the region will be Meskhetian Turk refugees processed in Krasnodar Krai, Russia.").

8. See id. (manuscript at 33) (stating that "success with this group may lead to the consideration of other minority groups long resident in Russia or other countries in the region that are unable to obtain citizenship or normal legal status.")

9. The Russian word "Krai" employed here is the rough equivalent of "region" and is used interchangeably throughout the text.

10. Proposed Refugee Admissions for FY 2006, supra note 7.

11. U.N. Hum. Rts. Comm'n (UNHCR), Executive Comm., Conclusions Adopted by the Executive Committee on the International Protection of Refugees, No. 50 (XXX1X), If J (1988), available at http://www.unher.org/cgi-bin/texis/vtx/excom [hereinafter Executive Comm. Conclusion] (all Executive Committee conclusions are available at http://www.unhcr.org/cgi-bin/texis/vtx/excom); Executive Comm. Conclusion, Conclusion on lnternational Protection, No. 89 (LI) (2000).

12. Executive Comm. Conclusion, Durable Solutions and Refugee Protection, No. 56 (XL) (1989)

13. Executive Comm. Conclusion, Voluntary Repatriation, No. 40 (XXXVI) (1985); See also Walter J. Brill, Book Review, 92 AM. J. INT'L L. 785 (1998) (reviewing Marjoleine Zieck, UNHCR and Voluntary Repatriation of Refugees: A Legal Analysis) (defining repatriation as "The return of a national by a state either from an overseas part or from another state following hostilities or worse.").

14. Executive Comm. Conclusion, Solutions and Protection, No. 63 (XL11) (1991); Executive Comm. Conclusion, International Solidarity and Refugee Protection, No. 52 (XXX1X) (I988); Executive Comm. Conclusion, Note on International Protection, No. 62 (XLI) (1990); Exccutive Comm. Conclusion, No. 68 (XL111) (1992); Executive Comm. Conclusion, Comprehensive and Regional Approaches Within a Protection Framework, No. 80 (XLVII) (1996); Executive Comm. 
Commissioner for Refugees (UNHCR) Executive Committee to address refugee crises.

The goal of each durable solution is to restore some form of national protection to refugees. Integration involves the long-term or permanent settlement of refugees in the country of first asylum. ${ }^{15}$ The success of local integration depends on the commitment of the host country to securing the refugees' human rights, providing access to livelihoods and means for economic survival, and providing opportunities to acquire citizenship and full integration into the host society ${ }^{16}$ Repatriation is the voluntary return of refugees to their country of origin. ${ }^{17}$ Often considered the preferred solution for the refugee, the choice of whether to return to the homeland must be voluntary and the home country must be able and willing to assume responsibility for ensuring refugees' legal and physical security. ${ }^{18}$ Resettlement is the transfer of a refugee from the country of first asylum to a third country that agrees to provide the refugee with protection. ${ }^{19}$ Most widely used as a solution to refugee outflows during the 1980 s when some 700,000 Vietnamese refugees were resettled, mainly in industrialized countries, resettlement is an appropriate protection strategy for those whose safety and security cannot be ensured in the country of first asylum. ${ }^{20}$ Resettlement is also a mechanism whereby wealthier countries can help preserve asylum by sharing responsibility for the global refugee problem. ${ }^{21}$

Viewing the experience of the Meskhetian Turks against the search for these durable solutions allows for a structured evaluation of the decision to resettle them in the United States and provides a framework for determining the eligibility of future refugee groups. In a post-September 11 context, the case of the Meskhetian Turks serves as a strong illustration that the United States should expeditiously use the remedy of resettlement for those groups at the greatest risk of harm. Specifically, the dire circumstances for ethnic minorities in post-Soviet space and the successful experience of newly resettled Meskhetian Turks in the United States

Conclusion, Conclusion on International Protection, No. 85 (XLIX) (1998); Executive Comm. Conclusion No. 87 (L) (1999).

15. UNHCR, The State of The World's Refugees: A Humanitarian Agenda 92-93, 96-97 (1997), available at http://www.unhcr.org/cgi-bin/texis/vtx/publ?id=3eefld896 [hereinafter STATE of THE WORLD's REFUGEES].

16. STATE OF THE WORLd's RefugeEs, supra note 15.

17. Executive Comm. Conclusion No. 40, supra note I3.

18. $l d$.

19. UNHCR, Resettlement: A Vital Instrument of International Protection and an Element of Comprehensive Solutions 1-3 (1997), available at http://www.unhcr.org/cgibin/texis/vtx/protect/opendoc.pdf?tbl=PROTECTION\&id=3d464b239 [hereinafter RESETTLEMENT HANDBOOK].

20. For a history of the asylum and resettlement of Indochinese refugees, see W. CourTLAND Robinson, Terms of Refuge: The Indochinese Exodus and the International Response (1998).

2I. Resettlement HANDBooK, supra note 19, at 7. 
should be cause to extend refugee eligibility to those ethnic groups similarly situated in the region.

Part 1 of this Comment introduces the transnational identity of the Meskhetian Turks, an ethnic group virtually non-existent in the United States before 2004. Because the Meskhetian Turks' long history of forced displacement figures prominently in finding the appropriate durable solution, this part explores two of the Meskhetian Turks' historical cataclysms: Stalin's mass deportation of the group in 1944 and their flight from pogroms in Uzbekistan to Russia in 1989.

Turning to a discussion of the forced statelessness and ethnic discrimination endured by the Meskhetian Turks in Russia's Krasnodar region, Part II discusses the failure of integration as a durable solution. An extreme case of state-sponsored ethnic discrimination in the former Soviet Union, Krasnodar demonstrates the ways in which state and non-state actors deploy rogue legal mechanisms and dispatch vigilante justice to impose a quasi-apartheid system on so-called illegal migrants, a category that encompasses Meskhetian Turks and other similarly situated ethnic minorities in the region.

Moving south of the Russian border, Part III demonstrates the shortfalls of relying on the post-Soviet republic of Georgia to facilitate repatriation of the Meskhetian Turks to their homeland, which lies in the southern region of the country. The issue of Meskhetian Turks' right of voluntary return raises important questions about Georgia's legal responsibility for repatriation of victims of Stalin's deportations as a successor state to the Soviet Union. Furthermore, it illustrates how Georgia's unwillingness to comply with its international obligations further intensifies the dire situation of the Meskhetian Turks in Krasnodar.

Part IV endorses the solution of third-country resettlement for the Meskhetian Turks against the backdrop of Russia's human rights abuses in Krasnodar and Georgia's unwillingness or inability to facilitate a genuine repatriation effort. This part explores the core factors that led to the opening of a special refugee program for Meskhetian Turks in 2004, including the effort to revitalize U.S. refugee admissions in a postSeptember 11 world. Based on the author's conversations with newly resettled Meskhetian Turks in the United States during 2004-2005, Part IV argues that resettlement to the United States is the most viable durable solution for this long-suffering population and a successful example of the U.S. refugee program. The case of the Meskhetian Turks should encourage the United States government to further expand the refugee resettlement program for groups similarly situated in the former Soviet Union, and in particular, in the Krasnodar region. At the same time, however, unless the U.S. government and international community combine the refugee program with a robust policy aimed at improving human rights in the Krasnodar region, resettlement will be at best an incomplete response. At 
worst, it could become a license for the local authorities to persecute other ethnic minorities.

\section{A Soviet Legacy: Stalin's CRImes and a Transnational Identity}

This section briefly introduces the complicated and tragic history of these new Americans-a history that spans across several states in the former Soviet Union and Turkey. Here the focus is primarily on the trajectory of those Meskhetian Turks who have recently resettled to the United States and hence lived, since 1989, in the Krasnodar region of the Russian Federation.

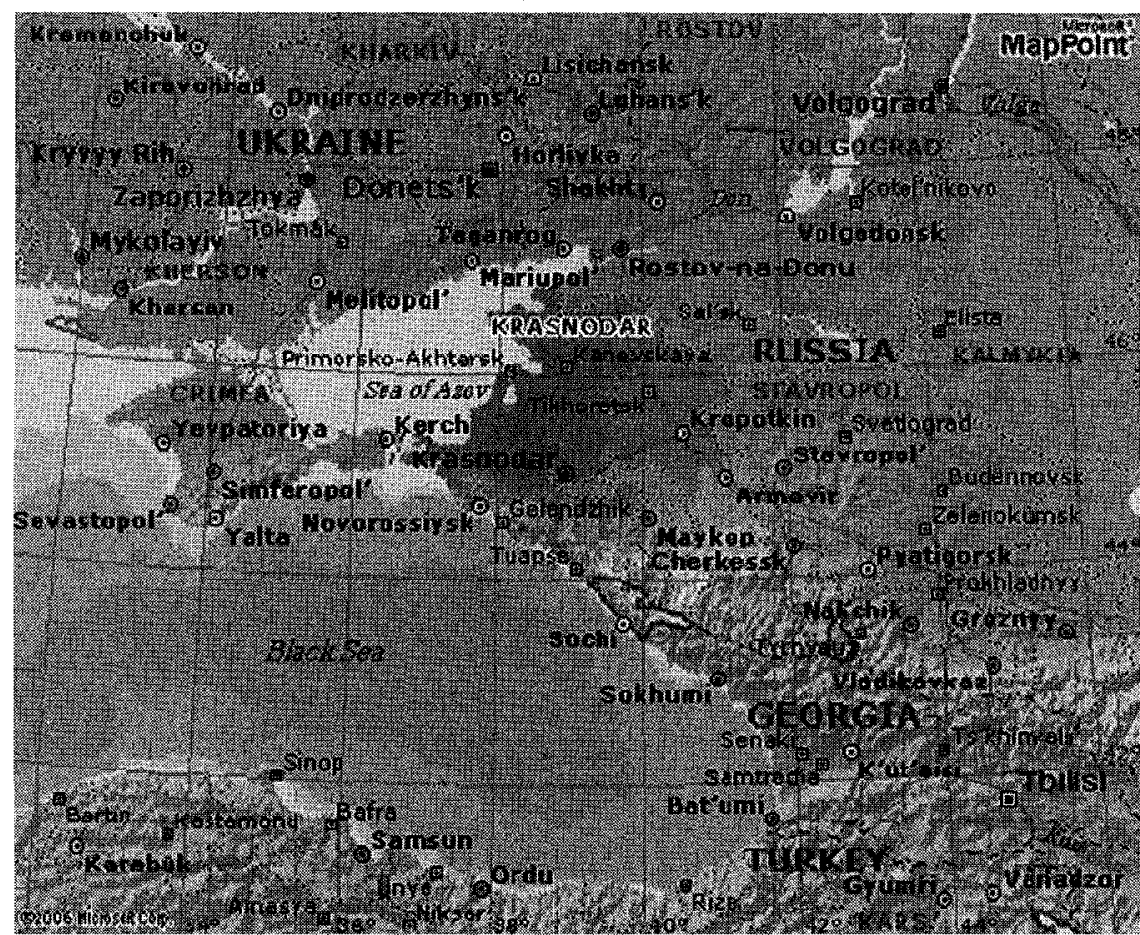

The above map shows both the administrative borders of the Meskhetian Turks' current home in Krasnodar Krai, in the southern part of the Russian Federation, as well as their ancestral home in southwestern Georgia, approximately halfway between the port city of Batumi and the capital city of Tbilisi, along the Turkish border. ${ }^{22}$

22. Republication permission provided by NAVTEQ. NAVTEQ is a registered trademark of NAVTEQ Corp. Map content (c)2006 NAVTEQ Corp. and the respective copyright holders. 


\section{A. Who Are the Meskhetian Turks?}

Meskhetian Turks are a group of Turkish-speaking people originally from Meskhetia (now known as Samtskhe-Javakheti), a part of southern Georgia that borders Turkey. The region of southern Georgia known as Meskhetia has the typical characteristics of an imperial borderland; it was disputed by several empires throughout the centuries, situated on trade and migration routes and subject to the influence of different cultures. ${ }^{23}$ The transnational character of the region mirrors the history of its people.

There is little consensus about whether the Meskhetian Turks are in fact ethnic Turks or rather ethnic Georgians who, at some stage in their history, adopted or were forcibly converted to Islam. ${ }^{24}$ In various times and circumstances, Meskhetian Turks have been labeled as "Turks," "Georgian-Sunnis," "Tatars," and even "Azerbaijanis," among other names. ${ }^{25}$ In Turkey, the group is called the "Ahiska Turks," which references Akhaltsikhe, the largest city in their native region of Samtskhe (present-day Georgia). ${ }^{26}$ Official Georgian Soviet and post-Soviet historiography mostly advocate the view that Meskhetian Turks are descendants of an ancient Georgian tribe "Meskhs" who converted to Islam due to Ottoman rule in southwest Georgia from the sixteenth through the nineteenth centuries. ${ }^{27}$ The counter argument, propagated by many Meskhetian Turk leaders, holds that the ancestors of Meskhetian Turks were people from Turkic tribes that settled in the region between the fifth and seventh centuries. ${ }^{28}$ Due to Ottoman rule, this view propounds, the local tribes effectively merged, thereby creating a new ethnicity: Meskhetian Turks. ${ }^{29}$ However important the origin of the Meskhetian Turks may be, the issue of terminology is highly charged, both politically and emotionally. Because the issue of origins should not distract

23. For an excellent treatment of Georgia's transnational history and the region of Meskhetia, see Ronald Grigor Suny, The Making of the Georgian Nation (2d ed. 1994).

24. Svetlana Chervonnaya, The Problem of the Repatriation of the Meskhet-Turks, Appendix to the Fact-finding Mission of the FUEN [Federal Union of European Nationalities] Delegation to Georgia, Nov. 1998, available at http://www.arts.uwaterloo.ca/MINELRES/ $\mathrm{min} / \mathrm{meskh} / \mathrm{FUEN}$ _Meskh.htm; Steve Swerdlow, Reflections on Transnational Minorities and Human Rights: Meskhetians and Hemshins in Georgia and Krasnodar, 5 Bull. ANTHropology, Minorities, Multiculturalism 6-9 (2004) [hereinafter Transnational Minorities].

25. Transnational Minorities, supra note 24.

26. Aysegul Aydingun, A Deported Nationality: The Ashiska Turks, Vol. 3, 4 PERCEPTIONS: J. OF INT'L AfFAIRS (1998-1999), available at http:/www.sam.gov.tr/perceptions/Volume3/Dec1998Feb1999/baydar.PDF.

27. Ludmilla Alexeyeva, Soviet Dissent: Contemporary Movements for National, Religious, ANd Human Rights 160-64 (1985); Nana Sumbadze, Muslim Population of Southern Georgia: Challenges of Repatriation, in Ethnic-Confessional Groups and Challenges to Civic integration in Georgia: Azeri, Javakheti Armenian, and Muslim Communities, 43-44 (Ghia Nodia ed., 2002).

28. Chervonnaya, supra note 24 .

29. Anatoly M. Khazanov, Meskhetian Turks in Search of Self-Identity, 11 CENTRAL ASIAN SuRVEY 1, 1-16, 12 n.4 (1992). 
from the practical goals of this analysis, this Comment does not explore the question of origin in great depth. This Comment does not use the term "Meskhetian Turks" as a statement indicating sympathies towards any of the opposing orientations, but rather exclusively for purposes of convenience. The term refers to the people deported by Stalin from southwest Georgia, today known as Samtskhe-Javakheti, during World War II.

\section{B. Enemies of the People}

By 1944, Stalin's paranoid nationality policy led to the deportation of peoples he considered even potentially disloyal ${ }^{30}$ Although he had already begun to cleanse political undesirables from border areas of the Soviet Union as early as the late 1920 s, Stalin aimed his wartime deportations at the total eradication of entire peoples. ${ }^{31}$ 1n late 1944, Stalin's right-hand man, Lavrenti Beria, passed a secret decree declaring the Meskhetian Turks, as well as Hemshins and Kurds - two peoples closely related to the Meskhetians-an "untrustworthy population" that should be immediately deported from the Georgian Soviet republic to Central Asia. ${ }^{32}$ Between November 15 and 26, 1944, Soviet troops forcibly removed approximately one hundred thousand Muslims from the Meskhetian region, confiscating their belongings and placing them on cattle cars destined for the Soviet republics of Kazakhstan, Kyrgyzstan, and Uzbekistan. ${ }^{33}$ Locked inside freight cars for one month, many did not survive the journey. In the words of one community leader:

At 4 a.m., four soldiers came into our house and said we had one hour to pack. We were not told where we would be sent. About 120 families were loaded into one freight car. We traveled 18 days and

30. For one of the most complete accounts of Stalin's deportations and their terrible aftermath, see Aleksandr M. Nekrich, The Punished Peoples: The Deportation and Fate of Soviet MinORITIES AT THE END OF THE SECOND WORLD WAR 42, 104-5 (1978).

31. Pavel Polian, Against Their Will: The History and Geography of Forced Migrations in the USSR 123-64 (2004); Yo'av Karny, Highlanders: A Journey to the Caucasus in Quest of Memory 360 (2000).

32. Sumbadze, supra note 27 , at $42-43$ (describing the order of deportation as "Decree no. $6279 \mathrm{ec}$ of the USSR State Committee of Defense," signed on July 31, 1944 to deport the "Turks, Kurds, and Khemshils" from Southern Georgia).

33. Polian, supra note 31, at 154-57. The official number of deportees from Georgia (dated in 1948) was 95,542 , of which most were Meskhetian Turks; 15,432 died en route or in exile. Also, Kurds (est. 3000) living in the same region as well as Khemsins (est. 1000; Armenians whose ancestors converted to lslam) and Terekeme (a Turkic pastoral nomadic tribe that arrived to the region from eastern Caucasus in the late 19th Century) were deported. It is worth noting that some people of Azeri and Laz nationality (also Muslim) living in the region were likewise deported. However, after the authorities realized the mistake they were allowed to return, whereas Meskhetian Turks, Khemsils and Terekeme were not. Extremely little is known about the deported Kurdish, Hemshin and Terekeme populations. However, it is known that in some localities they live together with Meskhetian Turks. 
nights to Central Asia. Many died of typhoid. At each stop they would unload the dead. ${ }^{34}$

Nearly a quarter of the Meskhetian population perished during the initial deportation to Central Asia, while many thousands more died from cold or hunger in their first years of displacement. ${ }^{35}$

The reasons behind Stalin's deportation of the Meskhetian Turks remain unexplained to the present day. The most commonly held view among historians is that Stalin and Beria viewed the Meskhetian Turks as potential subversive elements in the region given the proximity of the Turkish border ${ }^{36}$ The official Soviet justification followed the same pretext as the deportation of Chechens, Ingush, Balkar, Karachai, Crimean Tatars, and other peoples, namely alleged collaboration with Hitler, although at its closest, the German Army was more than one hundred miles away from Meskhetia. ${ }^{37}$ Some have also argued that Meskhetian Turks would have been a potential Fifth Column in Stalin's alleged plans to invade Turkey ${ }^{38}$

Following the initial trauma of deportation, the Soviet authorities dispatched the deported peoples into eighteen districts all over Uzbekistan, Kazakhstan, and Kyrgyzstan and forced them to live under "special settlement regimes" until 1956. ${ }^{39}$ Soviet authorities deprived deported persons of all civic and political rights and set most to work as agricultural laborers. ${ }^{40}$ Meskhetian Turks were forced to register each week with surveillance organs and were not entitled to travel anywhere outside of their settlement. Some of the local population was hostile to the newcomers, whom the NKVD, (People's Commissariat for Internal Affairs), the forerunner of the KGB, labeled as "enemies of the people."41 For the first twelve years of their exile, Meskhetian Turk special settlers' led lives of extreme deprivation, discrimination and constant supervision, and had almost no contact with the outside world. ${ }^{42}$

\section{Perpetual Exile}

In 1956, three years after Stalin's death, the new Soviet leader Nikita Khrushchev lifted many of the restrictions for Meskhetian Turks. ${ }^{43} \mathrm{He}$ also

\footnotetext{
34. Interview with Khasan S. in Vpered, Russia (July 2001) (on file with author).

35. Id.

36. Sumbadze, supra note 27 , at 42 .

37. Forced Migration Projects Open Society institute, Meskhetian Turks: Solutions and Human Security 3-6 (1998) [hereinafter Meskhetian Turks].

38. MESKHETIAN TURKS, supra note 37 , at 6.

39. Id. at 3-6; Aydingun, supra note 26.

40. PoliAn, supra note 31 , at 154-57.

41. Id.

42. POLIAN, supra note 31

43. Id. The USSR Supreme Soviet Decree No. 135/142 lifted some restrietions on deportees, although it did not allow them a right to return to the places of their original residenee. Another Supreme Soviet decree issued on October 31, 1957 allowed those persons deported from Georgia the right to resettle to Azerbaijan. On January 9, 1974, all the legislative acts officially restricting the right
} 
allowed the other deported peoples, such as the Chechens and Ingush, from the Caucasus to return to their territories ${ }^{44}$ However, unlike these groups, Soviet authorities neither rehabilitated nor allowed the Meskhetian Turks to return to their native land in Southern Georgia ${ }^{45}$ The Meskhetian region, known as Samtskhe-Javakheti, had become geo-politically important during the Cold War because it was adjacent to the border-zone between the Soviet Union and NATO and hence closed to the possibility of repatriation. ${ }^{46}$ Soviet Georgian authorities also opposed a repatriation of Meskhetian Turks, believing that their return would provoke antagonism between them and the Christian Armenians and Georgians living in Samtskhe-Javakheti. ${ }^{47}$ Some also attribute the refusal to allow Meskhetian Turks to return to the allegedly privileged position held by Georgian officials vis-à-vis the USSR government. ${ }^{48}$

Thus, with the exception of small numbers who migrated to other regions such as Azerbaijan, the majority of Meskhetian Turks continued to live in Uzbekistan, Kazakhstan, and Kyrgyzstan until 1989. ${ }^{49}$ The extremely harsh regime under which they lived as well as the juridical branding of the group as "enemies of the people" encouraged them to band together for physical and cultural survival. In this sense, the shared experience of deportation helped the Meskhetian Turks identify as a separate and distinct people. ${ }^{50}$

In June 1989, rising nationalist tensions led to the outbreak of a pogrom in the Uzbek section of the Fergana Valley, resulting in the deaths of about one hundred Meskhetian Turks. ${ }^{51}$ While the underlying causes of the pogrom are still ambiguous, the economic and political liberalization policies of the perestroika period, combined with the poverty and overcrowded conditions in the Fergana Valley, may have contributed to interethnic tensions. ${ }^{52}$ As a result, the Soviet army evacuated 17,000 Meskhetian Turks to Russia, triggering a larger outflow of another seventy

of Meskhetian Turks' return to Georgia were declared invalid. Nonetheless, this did not translate into a real possibility for repatriation.

44. Polian, supra note 31, at 199-201, 210-216.

45. KARNY, supra note 31 , at 125 .

46. Sumbadze, supra note 27 , at 45 .

47. Aydingun, supra note 26.

48. Meskhetian Turks, supra note 37.

49. Sumbadze, supra note 27 , at $44-46$.

50. Transnational Minorities, supra note 24 at 9 . In addition, their practice of not marrying outside their ethnic group contributed to the group's strong sense of identity. In Central Asia and other regions, Meskhetian Turks tended to live close to one another in rural or suburban settlements of anywhere from several dozen to a hundred or so households. As a rule, extended families remained close together and lived alongside those who had originated from the same villages in Meskhetia. Id.

51. Peter Gumbell, Economic Woes Set Off Uzbekistan Riots, WaLl ST. J., June 28, 1989, at A10.

52. MESKhetian TURKs, supra note 37, at 6-7. 
thousand from Uzbekistan as events quickly spiraled out of control. ${ }^{53}$ In addition, in the words of one Meskhetian Turk witness:

Uzbek crowds appeared on the streets and they were throwing stones and threatening people.... We became very afraid when we heard that in other places they [Uzbeks] were burning houses and killing people, so we fled... We left in such a hurry that we had no time to collect any possession[s]. We didn't even take our documents .... It was devastating to leave. With hard work people had built a nice life and we had to leave with nothing. ${ }^{54}$

The majority of displaced Meskhetian Turks settled in Azerbaijan ${ }^{55}$ while others settled in Ukraine, as well as the republics adjacent to Uzbekistan-Kyrgyzstan and Kazakhstan. Many others found their ways to different parts of central and southern Russia, in particular to the region of Krasnodar Krai. ${ }^{56}$

\section{No Return Home}

From the moment Khrushchev lifted the special settlement regime in 1956, Meskhetian Turks fought for the right to return to their homeland in Georgia. ${ }^{57}$ Pursuing their goal through the establishment of their own political organizations such as Vatan and the Union of Georgian Repatriates, the Meskhetian Turks' struggle for repatriation constituted an important movement of public activism and resistance to Soviet authority during the Soviet period. ${ }^{58}$ With the exception of a small number of Meskhetian Turk families who managed to return semi-legally to other parts of Georgia between 1956 and the late $1980 \mathrm{~s},{ }^{59}$ Soviet and Georgian authorities consistently prohibited the return of the Muslim Meskhetian Turks to the overwhelmingly Christian nation of Georgia ${ }^{60}$ One Meskhetian Turk who managed to reenter Georgia unofficially in the early 1980s was willing to sacrifice everything, including his physical safety, to satisfy his longing to be back on his own soil:

I used to live in Kazakhstan, then in Azerbaijan, and was making a good living there. But I always felt a hole in my life. I finally said

\footnotetext{
53. Moscow Helsinki group, Human Rights in Russian Regions Report 2001232 (2002).

54. MESKHETIAN TURKS, supra note 37 , at 6.

55. KARNY, supra note 31 , at 125.

56. The present day Meskhetian Turk community makes up a transnational population numbering nearly 400,000 people and stretching across nine nation states. The majority of these communities find themselves in the Commonwealth of Independent States (CIS) (Azerbaijan, Georgia, Kazakhstan, Kyrgyzstan, Russia, Ukraine, and Uzbekistan), while others live in Turkey and, since the summer of 2004, the United States.

57. ALEXEYEVA, supra note 27.

58. Id.

59. Marat Baratashvili, Legal State of the Meskh Repatriates 16 (1998) (on file with author).

60. SUNY, supra note 23 , at 163.
} 
to myself, 'Let me be poor and return to a country with so much turmoil but let it be my homeland, Georgia. ${ }^{.61}$

When Georgia became independent in 1991, a hard-line nationalist, Zviad Gamsakhurdia, became the country's first president, and hopes for repatriation soon evaporated amidst the leader's calls of "Georgia for Georgians!"'62 By 1992, most of those who managed to return were expelled from the country. ${ }^{63}$ A consistent centerpiece of the refusal to repatriate the Meskhetian Turks has been the fact that ethnic Armenians share the region from where the Muslim and Turkish-speaking Meskhetian minority were deported; hence, their return would hastily trigger an ethnic conflict. $^{64}$ After assuming leadership of the troubled republic in 1992, Eduard Shevardnadze reversed the state's overtly xenophobic policy toward the issue of return. ${ }^{65}$ However, neither Shevardnadze nor his successor, Mikheil Saakashvili-seen by the West as a champion of democracy-have demonstrated any real political will to begin repatriation. ${ }^{66}$

Unable to return to Georgia and Uzbekistan, the Meskhetian Turks of Krasnodar began a new chapter of their history in Russia. The most bitter irony is that their new place of asylum is a hotbed of ethnic discrimination, where for the last fifteen years they have been threatened with the possibility of yet another deportation. This Comment now turns to the current human rights catastrophe of the Meskhetian Turks in Krasnodar Krai and the failure of the Russian government to adequately pursue integration as a genuine solution.

\section{II \\ Integration: A Human Rights Catastrophe in Krasnodar Krai: I 989-PRESENT}

Alongside the war in Chechnya, the situation of the Meskhetian Turks of Krasnodar Krai is the leading and most long-standing example of collcctive ethnic discrimination in the Russian Federation today. ${ }^{67}$ While migrants and ethnic minorities face discrimination throughout post-Soviet society ${ }^{68}$ Krasnodar Krai presents a special case of what some call "soft

61. Interview with Muhammad S. in laneti, Geor. (Aug. 2002) (on file with the author).

62. SunY, supra note 23.

63. Chervonnaya, supra note 24; SunY, supra note 23.

64. Chervonnaya, supra note 24.

65. SUNY, supra note 23; MESKHETIAN TURKS, supra note 37.

66. SUNY, supra note 23.

67. For an excellent background on the propiska, see HUMAN Rights WATCH, Ethnic Discrimination in SOUtheRn Russia (1998), available at http://www.hrw.org/reports98/ russia/srusstest-04.htm\#P283_66675 [hereinafter EThNic Discrimination IN SOUTHERN RusSia]

68. C.J. Chivers, Moscow Journal: Strange City. Thankless Job. Heartless Russian Winter, N.Y. TImEs, Mar. 3, 2006, at A4. 
ethnic cleansing." ${ }^{\text {.9 }}$ A multiethnic province situated in Russia's north Caucasus, Krasnodar became notorious during the 1990s for the xenophobia and anti-Semitism of its firebrand governor Nikolai Kondratenko. ${ }^{70}$ Reputed for his public exhortations to fight the "global Zionist conspiracy,"71 and his disdain for non-Slavic ethnic minorities, Kondratenko supported numerous pieces of regional legislation to disenfranchise the Meskhetian Turks and offered official support to violent neo-Cossack paramilitary groups. In late 2000, Alexander Tkachev, a former collective farm director and protégé of Kondratenko, won a landslide gubernatorial victory running on a continuation of his mentor's populist policies. ${ }^{72}$ On March I8, 2002, in a notorious speech that set the tone for his governorship, Tkachev proposed creating "filtration camps"73 throughout the territory to detain and deport illegal migrants with nonSlavic surnames. In addition, he called for expelling the Meskhetian Turks by way of charter flights to Uzbekistan and stated his willingness to initiate high-level negotiations with Armenian President Robert Kocharian for the repatriation of all ethnic Armenians "back to their country."

Sadly, on its own, this type of populist rhetoric may be atypical for other regions in Russia, such as Moscow and St. Petersburg, where antimigrant hysteria has grown dramatically in the years since the collapse of the Soviet Union. ${ }^{75}$ In particular, Russia has witnessed an explosion in recent years of neo-Nazi hate crimes and racially motivated murders and assaults against Jews, persons from the Caucasus, Central Asia, and foreign students mainly from developing countries. ${ }^{76}$ However, these

69. See Memorial Human Rights Center, Stop Ethnic Cleansing! Statement of the Human Rights Centre Memorial Concerning Persecutions of the Meskhetian Turks and other Ethnic Minorities in the Krasnodar Region of the Russian Federation, Apr. 9, 2002, available at http://refugees.memo.ru/for_all/rupor.nsf/c229ccef27c3bda6c3256a530068f234/fca8cd43c0b9ce0ac32

56ba0007b9d7c?OpenDocument [hereinafter Stop Ethnic Cleansing!]; Michael Slackman, The Shadow People, Seattle Times, June 19, 2000, at A3 (emphasis added) [hereinafter The Shadow People].

70. UNION OF COUNCILS FOR SOVIET Jews, ANTISEMITISM, XeNophobia and Religious PERSECUTION IN RUSSIA's REgIONS 200I 10-22 (2002), available at http://www.fsumonitor.com/ russiabook2001/Russia_Book_2001_Main_v2_pt2.pdf [hereinafter UCSJ RUSSIAN REGIONAL REPORT $200 \mathrm{I}]$.

71. MosCow HeLSINKI GROUP, supra note 53 at 234.

72. UCSJ RUSSIAN REGIONAL REPORT 2001, supra note 70.

73. See Memorial Human Rights Center, infra note 244.

74. Stop Ethnic Cleansing!, supra note 69; See Izvestiya, Mar. 20, 2002 (Russian News Daily):

The Govcrnor of Krasnodar krai announced the beginning of a campaign against ethnic migration. At a meeting of the local administration, he declared that "thc Kuban is Cossack land, and everyone needs to know about this. We will increase in the coming days the fines for a lack of registration papers up to 6000 rubles. This will lead illegal migrants to leavc the krai territory. We will see who is befriending who, and we will pay attention to people's surnames!

75. ETHNic Discrimination in SOUTHERn RusSia, supra note 67.

76. Union of Councils for Soviet Jews, Bloody April: The Escalation of Neo-Nazi Violence in Russia, May 19, 2006, available at http://www.fsumonitor.com/stories/051906Nick2.shtml (stating that "[w] hen it comes to racist violence, April 2006 will go on record as the bloodiest month in recent Russian history, with at least seven murders and more than a dozen assaults attributed to neo-Nazi 
populist initiatives represent actual efforts of the Krasnodar authorities to elevate xenophobia against non-Slavic minorities to the level of public policy and affirmatively to keep the Meskhetian Turks, along with other smaller ethnic groups, a perpetually stateless people. As this section demonstrates, integration remains an elusive goal for Meskhetian Turks in Krasnodar Krai given the unending campaign of Krasnodar's local authorities to use the old Soviet passport system, known as the propiska, to discriminate against Meskhetian Turks in all spheres of life, denying them their civil, political, social, and economic rights. Rather than integration, the Krasnodar authorities' open support for Cossack vigilante groups who target Meskhetian Turks and other minorities, illustrates a policy of expulsion.

\section{A. State-Sponsored Discrimination in Practice: Citizens or Illegal Migrants?}

In contrast to other regions of Russia where they have lived since fleeing Uzbekistan in 1989, the local authorities of Krasnodar Krai refuse to recognize the nearly fourteen thousand Meskhetian Turks who have resided there for over fifteen years as citizens of the Russian Federation. ${ }^{77}$ In contravention of the Russian Constitution and federal citizenship laws, the regional authorities deny Meskhetian Turks the right to register their residence in the territory based on the argument that they are "illegal migrants." ${ }^{\text {W }}$ Without registration, the Meskhetian Turks are effectively stateless persons without basic civil and human rights. Trapped in a cruel legal limbo for the last fifteen years, the state-controlled local media frequently demonize Meskhetian Turks as "illegal migrants" who pose an "ethno-demographic" threat to the region's stability. ${ }^{79}$

The Krasnodar authorities render Meskhetian Turks stateless using the notorious propiska, which roughly translates as a residence permit. ${ }^{80}$ The propiska is a vestige of the Soviet passport system used to regulate a person's permanent residence and to monitor movement throughout the

groups.") The murders included the beating to death of a fifty-year-old Vietnamese man in the town of Ostrogozhsk (Voronezh region) on April 6; the ambush and murder of a Senegalese student on April 7 in St. Petersburg, where police found a shotgun with a swastika on it near the seene; a skinhead mob killing of two Roma (Gypsy) on April 13 in Volzhsky (Volgograd region); a racist murder of a thirtythree-year-old citizen of Azerbaijan in Novy Urengoy (Yamal-Nenets Autonomous District) on April 21 ; and the stabbing to death of an Armenian teenager, Vigen Abramyants, by a skinhead while he was standing while waiting for a metro train on a crowded platform. Id.

77. Alexander Osipov \& Olga I. Cherepova, The Violation of the Rights of Forced Migrants and Ethnic Discrimination in Krasnodar Territory: The Situation of the Turks-Meskhetians 23 (1996) [hereinafter The Situation of the Meskhetian Turks].

78. Id.

79. Id.

80. For an excellent analysis of the propiska see SvetLana GanNushinina, The Institute of THE PROPISKa (Residence Registration) AND ITS Evolution, (2003), available at http://refugees.memo.ru/for_all/rupor.nsf; See also EThnic Discrimination In SOUTHERn Russia, supra note 67. 
country ${ }^{81}$ At the height of the perestroika period, a Soviet Committee for Constitutional Review found the propiska illegal and held "the use of the propiska for permitting or denying residence and movement violate[d] citizens' fundamental rights to move freely, to gain employment, and to receive an education. ${ }^{\prime 82}$ Shortly after independence, the Russian Duma enshrined guarantees of the freedom of movement and the freedom to choose one's place of residence in the Constitution, ${ }^{83}$ and formally abolished the propiska as a mechanism for regulating a person's right to acquire residency status in $1993 .^{84}$ But in open defiance of federal law, Krasnodar's regional authorities still insist on preserving the propiska as a means for controlling the in and out-flow of migrants. Persons who lack permanent residence registration are virtually devoid of all rights. Without a propiska, the Meskhetian Turks have no rights to own property, to employment, to register their marriages, to obtain a passport or other personal identification, to enter public institutions of higher education, or to receive proper birth certificates, and have no access to social security pensions or healthcare benefits. ${ }^{85}$ Thus, the Krasnodar authorities' current use of the propiska to disenfranchise the Meskhetian Turks and as a tool to control regional migration is a gross violation of federal law.

Moreover, the Meskhetian Turks should be considered Russian citizens under Russia's 1991 law on the "Citizenship of the Russian Federation." citizens who permanently resided on Russian territory when the law came into effect automatically became Russian citizens in February 1992. ${ }^{87}$ However, the Krasnodar authorities insist in numerous official pronouncements and legislative acts that the Meskhetian Turks are "illegal migrants temporarily residing on the territory of Krasnodar Krai. ${ }^{" 88}$ For

81. Ethnic Discrimination in Southern Russia, supra note 67.

82. Itogi Komiteta Konstitutsionnogo Nadzora, RSFSR [Conclusions of the Committee of Constitutional Review, Russian Soviet Federal Socialist Republic] October 29, 1990.

83. Konstitutsiia Rossiiskoi Federatsii [Konst. RF] [Constitution] art. 42.

84. In 1993, the Duma passed a bill "on the right of Russian citizens to freedom of movement, choice of residence and domicile within the territory of the Russian Federation," which took effect on October 1, 1993, and abolished the propiska as a mechanism for the grant or denial of residency status and all its corresponding citizenship rights. In December 1993, the right to freedom of movement and the choice of one's place of residence became a part of the second Russian Constitution, which came into being that year. See Konstitutsiia Rossiiskoi Federatsii [Konst. RF] [Constitution] art. 27.

85. Allan Thomspon, 'Even a Bird Has a Homeland,' Toronto Star, Jan. 24, 1999.

86. Federalnyi Zakono Grazhdanstve Rossiskoi Federatsii [Federal Law on Citizenship of the Russian Federation] 1992, art. 13, sec. 1.

87. Id.

88. See "On Measures to Prevent Illegal Migration into Krasnodar Krai," No. 735-K3, July 2, 2004; See also "Resolution of the Head of Administration of the Krasnodar Area on Strengthening of Control over Migration Processes on the Territory of the Krasnodar Area," No. 222, Apr. I9, 1994, available at http:/www.unhcr.org/cgi-bin/texis/vtx/home/ opendoc.htm?tbl=RSDLEGAL\&page=research\&id=3ae6b500I3. Several other pieces of Krasnodar regional legislation implement the unconstitutional use of the propiska regime and carve out special restrictions on Meskhetian Turks. Some examples of these are "On the Regulation of Migration in 
example, Krasnodar regional legislation requires Meskhetian Turks to reregister as "guests" every forty-five days in order to gain "temporary residency status," and empowers law enforcement bodies to carry out raids to apprehend those with improper registration documents. ${ }^{89}$ ln March 2002, Tkachev authorized police to conduct operation Foreigner, which was aimed at identifying and fining thousands of allegedly illegal migrants for improper registration..$^{90}$

Hence, Meskhetian Turks are de jure Russian citizens, but their treatment renders them de facto stateless persons. In immigration and all other spheres Russian federal law preempts regional legislative acts, which are valid only to the extent they are consistent with the Constitution. Nonetheless, despite Krasnodar's unconstitutional use of the propiska to curtail migration and its blatant affront to the Kremlin's federal authority, Moscow has refused to curtail the Krasnodar authorities from enacting a "censorship on settlement."

Lack of citizenship and registration has led to the creation of a quasiapartheid system for the Meskhetian Turks in Krasnodar. Remarkably, the local authorities have created a situation in which hundreds, potentially thousands, of Meskhetian Turkish children born since 1991 have no birth certificates, and hence no legal identity. ${ }^{92}$ The Krasnodar administration's position that Meskhetian Turks are illegal has also inspired school officials to create segregated classrooms for Meskhetian Turk children, ostensibly due to their unwillingness to learn correct Russian. ${ }^{93}$

Among the most severe violations of the Meskhetian Turks' human rights is the inability to earn a livelihood. Without a propiska, they cannot rent plots of agricultural land or trade in the marketplace in the mostly rural regions where they have settled. ${ }^{94}$ According to human rights activist Alexander Osipov, the local government adopted this strategy to "starve minorities out of the Krai" by depriving them of any source of income. ${ }^{95}$ In an interview with the Washington Post, one Meskhetian Turk in the Krasnodar village of Varennikovskaya identified the motivation behind the

Krasnodar Krai," Decision of the Regional Soviet No. 148, Apr. 14, 1990; "Resolution of the Head of Administration of Krasnodar Krai on Measures to Regulate Migration Processes on the Territory of Krasnodar Krai," No. 494, Dec. 23, 1993; "On the temporary regime of registration of refugees and forced migrants," No. 400, Aug. 31, 1992.

89. Alexander Osipov, Meskhetian Turks in Krasnodar on the Brink of Expulsion, RFE/RL, Vol. 3, No. 15, Apr. 10, 2002, available at http:/www.rferl.org (archive) [hereinafter Brink of Expulsion] (on file with the author).

90. Press Release, Novorossiysk Committee for Human Rights (NCHR) (Mar. 26, 2003) (on file with author).

91. Moscow Hel.SINKI GROUP, supra note 53. at 234.

92. Press Release, Novorossiysk Committee for Human Rights (NCHR) (Jan. 28, 2003) (on file with author).

93. Press Release, Novorossiysk Committee for Human Rights (NCHR) (Mar. 26, 2003) (on file with author).

94. Brink of Expulsion, supra note 89.

95. Interview with Alexander Osipov in Tbilisi, Geor. (June 2002) (on file with author). 
authorities' policies. "It's the twenty-first century, and they want to deport people on the basis of ethnicity.... They are persecuting us so we will be forced to leave."'96

Beyond this tactic of soft ethnic cleansing, Governor Tkachev has repeatedly called for the deportation of illegal migrants from the territory and has pressured regional courts to issue orders for expelling Meskhetian Turk and other ethnic minorities. ${ }^{97}$ "Our goal is to make clear to all illegal immigrants that Russia is not a revolving door," Tkachev was quoted as saying at a local migration conference..$^{98} \mathrm{He}$ pointedly suggested that authorities should crack down on all those living in Krasnodar with nonRussian last names. ${ }^{99}$ In the autumn of 2001 , extremist groups took his words literally and forcibly expelled more than one hundred Roma (Gypsies) from the Krasnodar region to the city of Voronezh. ${ }^{100}$

Police also routinely round up and detain Meskhetian Turks for hours on the pretext that they have violated registration laws. "They catch me as soon as 1 leave my house or when I am working at the market. They look at my temporary registration and tell me it has expired. I have to pay a fine or they'll detain me." 101 There is also a financial stimulus involved in arrests and detentions. Fines can reach more than ten thousand Russian Rubles (approximately 300 U.S. dollars), which is much higher than an average Meskhetian Turk family's monthly income. In an interview, a woman described the harassment and systematic extortion she faces trading in the marketplace:

A police officer will come to check documents. We stand there alongside the Russian vendors but every time they approach us because we are dark-skinned. They want to see all kinds of different licenses and if we don't have all of them they fine us. Can you really be expected to bring all your documents with you to work every day? ? $^{102}$

96. Interview Sarvar Tedorov, Meskhetian Turk Human Rights Activist, in Varennikovskaya, Russ. (Aug. 2004) (on file with author).

97. Interview with Evgenii Gaidash, Human Rights lawyer and Director of Non-governmental Organization Good Deed (Dobroe Delo) Krasnodar, Russ. (July 2004) (on file with author). Gaidash reported that his organization, in conjunction with the Memorial Human Rights Center and the European Human Rights Advocacy Center, has filed complaints on behalf of several Meskhetian Turks who were ordered deported from Krasnodar Krai in the European Court of Human Rights. The applicants allege the orders for their expulsion violate Articles 3, 6(1),6(3), 8, 13, and 14 of the European Convention for the Protection of Human Rights and Fundamental Freedoms (ECHR), and Article 3(1) of the Fourth Protocol to the ECHR. (complaints on file with author).

98. See Izvestiya, supra note 74 .

99. Id.

100. Dep't of State, Bureau of Labor, Democracy, and Human Rights, Country REPORTS: RUSSIAN FEDERATION 2003, Feb. 24, 2004, available at http:/www.state.gov/g/ $\mathrm{drl} / \mathrm{rls} / \mathrm{hrrpt} / 2003 / 27861$.htm.

101. Interview in Vpered, Russ. (Jul. 2001) (on file with author).

102. Id. 
Journalist Michael Slackman captured the essence of the Meskhetian Turks' predicament in Krasnodar when he reported in 2000 that "[w]ithout legal standing, they have become shadows prevented from joining the everyday life of their community." 103

In addition to contravening Russian law, the treatment of the Meskhetian Turks in Krasnodar violates several of the Russian Federation's obligations under international law. ${ }^{104}$ In a recent report, the Council of Europe reiterated the findings made by the Commissioner for Human Rights and the Parliamentary Assembly of the Council of Europe after his 2004 visit to Krasnodar Krai, who described the situation of the Meskhetian Turks as "nothing short of a disaster." 105 The Commissioner also considered it "unacceptable for a small group of persons to be deprived of all civic rights simply on the basis of their ethnic affiliation." 106 The Parliamentary Assembly of the Council of Europe also adopted a resolution on the situation of the Meskhetian Turks in March 2005, in which it noted:

[S]ince the Meskhetian Turks are refused residence registration and are not recognised as citizens of the Russian Federation, they are deprived of basic civic, political, economic and social rights. This situation, which exists to this very day, is unacceptable. It is furthermore particularly worrying that the regional administration applies deliberately discriminatory practices with respect to Meskhetian Turks. ${ }^{107}$

103. The Shadow People, supra note 69 (emphasis added).

104. The Soviet Union was party to the major international human rights instruments applicable to the Meskhetian Turks, including the International Covenant on Economic, Social and Cultural Rights (ICESCR), the lnternational Covenant on Civil and Political Rights and its Optional Protocol (ICCPR), the International Convention on the Elimination of All Forms of Racial Discrimination (CERD), the International Convention on the Suppression and Punishment of the Crime of Apartheid, the UNESCO Convention against Discrimination in Education, and the ILO Convention (No.11I) concerning Discrimination in Respect of Employment and Occupation. As a successor state to the Soviet Union, Russia is bound to uphold these treaties. The Russian Constitution explicitly recognizes the binding nature of international law, stating:

[U]niversally recognized principles and norms of the international law and the international treaties of the Russian Federation are a component part of its legal system. If an international treaty of the Russian Federation stipulates other rules than those established by the law, the rules of the international treaty shall apply.

Konstitutsiia Rossiiskoi Federatsii [Konst. RF] [Constitution] art. 15, part 4. Since independence, the Russian Federation has also signed and ratified a number of Council of Europe treaties including the European Convention for the Protection of Human Rights and Fundamental Freedoms (ECHR), the Framework Convention for the Protection of National Minorities (FCNM), and several others.

105. See Eur. Comm'n Against Racism and Intolerance, Third Report on the Russian Federation, (Dec. 16, 2005), para. 108-111, available at http://www.coe.int/T/E/human_rights/Ecri/1 ECRI/2Countrybycountry_approach/Russian_Federation/Russian_Federation_CBC_3.asp\#P439_7741 0 (discussing the need for urgent action to end the discriminatory treatment of Meskhetian Turks by local authorities in regards to 'registration of residence and enjoyment of civil, political, and socioeconomic' and citizenship rights) (internal quotations omitted).

106. Id. (internal quotations omitted).

107. Id. 
By directly supporting and failing to put an end to the discriminatory actions of the Krasnodar regional authorities, the Russian Federation has violated its international human rights obligations found in several binding treaties concerning guarantees of Meskhetian Turks' civil, political and socio-economic rights. While it is beyond the scope of this Comment to address every violation of international law, it is important to recognize the most prominent among them. The Krasnodar authorities' refusal to recognize the Meskhetian Turks' citizenship violates Article 16 of the International Covenant on Civil and Political Rights (ICCPR) ${ }^{108}$ which guarantees recognition as a person before the law as a universal right. The targeting of Meskhetian Turks for arbitrary detention and administrative arrests violates Articles 9(1) and 17 of the ICCPR ${ }^{109}$ and the use of the Soviet propiska system to deny the freedom of movement and choice of residence contradicts Article 12(1). ${ }^{110}$ Moreover, the systematic refusal to register marriages, issue birth certificates, and the non-recognition of fatherhood violate Articles 23(2) and 24."11 Overall, the general discriminatory treatment of the Meskhetian Turks in the region violates the prohibition of discrimination found in Article 26. ${ }^{112}$ The European Convention for the Protection of Human Rights and Fundamental Freedoms (ECHR), the most important regional human rights instrument to which Russia is a party, largely mirrors these provisions. ${ }^{113}$

The authorities' non-recognition of Meskhetian Turks' right to work violates Article 6(1) of the International Covenant on Economic, Social and Cultural Rights (ICESCR). ${ }^{114}$ Specific regional legislation aimed at barring the Meskhetian Turks any sources of income violates Article 11, ${ }^{115}$ which includes the right of every person to an adequate standard of living, including adequate food, clothing, and housing and the fundamental right to be free from hunger. Additionally, the practice of barring Meskhetian Turks from access to health care, social security benefits, and pre-school education for minors contradicts Article 10(1). ${ }^{116}$ The denial of equal educational opportunities violates Article I3. ${ }^{117}$ Several NGO activists from the region have also brought complaints of educational discrimination

108. Intemational Covenant on Civil and Political Rights and Optional Protocol to the International Covenant on Civil and Political Rights art. 16, Dec. 19, 1966, 999 U.N.T.S. 171 [hereinafter ICCPR].

109. Id.

110. $I d$.

111. Id.

112. Id.

113. European Convention for the Protection of Human Rights and Fundamental Freedoms, Nov. 4, 1950, 213 U.N.T.S. 221 [hereinafter ECHR].

114. Intcrnational Covenant on Economic, Social and Cultural Rights, Dec. 16, 1976, 993

U.N.T.S. 3 (entered into force Jan. 3, 1976) [hereinafter 1CESCR]

115. Id

116. Id.

117. Id. 
against the Meskhetian Turks in Krasnodar before the UN Committee on the Rights of the Child. ${ }^{118}$

The range of policies aimed at the persecution and expulsion of Meskhetian Turks as a group from the Krasnodar region violate the antidiscrimination principles found in Article 2,3,5, and 6 of the International Convention on the Elimination of All Forms of Racial Discrimination (CERD) ${ }^{119}$ In particular, by allowing the regional authorities to impose statelessness on an entire group, the Russian Federation tolerates and encourages discrimination against Meskhetian Turks based on their ethnicity, national origin, and place of residence. By perpetuating a Soviet passport system, Russia preconditions the enjoyment and exercise of almost every entitlement and freedom on the possession of registration. In a March 2004 report on compliance with the Covenant, the UN CERD Committee specifically condemned the Russian Federation for allowing Krasnodar officials to segregate Meskhetian Turk children into separate and inferior classrooms in the villages where they reside. ${ }^{120}$

In addition to anti-discrimination guarantees, Russia is obligated to observe a range of minority rights protections for the Meskhetian Turks. ${ }^{121}$ The general discriminatory treatment of the Meskhetian Turks constitutes a blatant violation of Article 4(1) of the Framework Convention for the Protection of National Minorities (FCNM), which stipulates: "[p]arties undertake to guarantee to persons belonging to national minorities the right of equality before the law and of equal protection of the law." 122 The statesponsored campaigns for the expulsion of the Meskhetian Turks contradict Article 6(1) and official support for Cossack paramilitary units directly contravenes Articles 6(2) and I6 of the FCNM. ${ }^{123}$

118. Convention on the Rights of the Child, Nov. 20, 1989, 1577 U.N.T.S. 3 [hereinafter UNCRC]; See also Press Release, Novorossiysk Committee for Human Rights, The Decisions of the UN Committee on the Rights of Child Will Be Ignored (Nov. 23, 2005) (on file with author).

119. International Convention on the Elimination of All Forms of Racial Discrimination, December 21, 1965, 660 U.N.T.S. 195 (entered into force Jan. 4, 1969) [hereinafter CERD].

120. UNHCR, Comm. on Elimination of Racial Discrimination, Concluding Observations of the Committee on the Elimination of Racial Discrimination, U.N. Doc. CERD/C/62/CO/7 (Mar. 21, 2003).

121. Framework Convention for the Protection of National Minorities, opened for signature Feb. 1, 1995, C.E.T.S. No. 157 (entered into force Feb. 1, 1998), available at http://conventions.coe.int/Treaty/en/Treaties/Html/157.htm [hereinafter FCNM]; see also European Charter for Regional or Minority Languages, opened for signature May 11, 1992, C.E.T.S. No. 148 (entered into force Jan. 3, 1998), available at http://conventions.coe.int/Treaty/en/Treaties/ $\mathrm{Html} / 148 . \mathrm{htm}$; European Convention on Nationality, opened for signature June 11, 1997, C.E.T.S. No. 166 (entered into force Jan. 3, 2000), available at http://conventions.coe.int/ Treaty/en/Treaties/Html/166.htm; Protocol No. 12 to the European Convention of Human Rights and Fundamental Freedoms, opened for signature Apr. 4, 2000, C.E.T.S. No. 177, available at http://conventions.coe.int/Treaty/en/Treaties/Html/177.htm.

122. FCNM, supra note 21, art. 4.

123. Id. art. 6(2), 16. 


\section{B. Local Discourses of Discrimination: Why Krasnodar?}

Meskhetian Turks living in other parts of Russia also encounter various degrees of official harassment and antipathy from local populations, but their general conditions are unquestionably better when compared to those in Krasnodar Krai. ${ }^{124}$ In fact, the majority were able to receive Russian citizenship under the 1991 Law on Citizenship. ${ }^{125}$ This discrepancy prompts one to ask why the persecution in of Meskhetian Turks in Krasnodar Krai became so pronounced, while other Russian regions generally allowed for their integration. One answer may lie in the way nationalist leaders in Krasnodar are effectively able to mobilize local discourses of racism and xenophobia among extremist groups and the media. During perestroika and throughout the 1990s, Krasnodar witnessed a revival of Cossack nationalism in which reactionary scholars and members of the media gradually formulated the core of a racist ideology directed at non-Slavic peoples. ${ }^{126}$ Ideologues of this movement propagated pseudo-scientific theories proving the "incompatibility of Slavic and Turkish populations," predicting the outbreak of ethnic conflict if the Meskhetian Turks and other minorities were allowed to upset the region's fragile "ethno-demographic balance." 127 The local state-controlled media also promulgated and reinforced xenophobia by consistently whipping up hysteria against the Meskhetian Turks and other ethnic minorities. ${ }^{128}$

\section{Cossacks'Vigilante Justice}

Unfortunately, the official policy of discrimination pursued against the Meskhetian Turks is not limited to discriminatory laws, xenophobic discourse, and cconomic pressure. Meskhetian Turks are also victims of intimidation and violent attacks by neo-Cossack paramilitary organizations, which enjoy official support from local authorities and operate as a kind of shadow law enforcement. ${ }^{129}$ According to a human rights report, at the end of 2000, approximately 15,700 Cossacks were registered as soldiers in the region, and 283 Cossack paramilitary units (druzhiny) with over five thousand members operate in Krasnodar. In addition, over 100 members of the Cossack organizations have been

124. Sumbadze, supra note 27 , at 47

125. MesKhetian TuRKs, supra note 37, at 8-11.

126. The Situation of The Meskhetian TuRKs, supra note 77, at 58-63.

127. MOSCOW HELSINKI GROUP, supra note 53 at 233.

128. See UCSJ RUSSIAN REgIONAL REPORT 2001, supra note 70 (citing various Russian newspaper articles printed in the Krasnodar press).

129. Alex Rodriguez, Cossacks: Guardians or Oppressors? Putin Wants to Legitimize the Warriors, But the Muslim Groups They Persecute Don't Feel the Same, CHIC. TRIB., Aug 7, 2005, at 3.; see also The Situation of the Meskhetian Turks, supra note 77, at 64-66. 
elected to public office in the region. ${ }^{130}$ A February 2001 article in the Russian daily Izvestiya also reported that there are over thirty Cossack groups in Krasnodar Krai. ${ }^{131}$

Descendants of the fierce fighters who once guarded the imperial borders of tsarist Russia, Krasnodar's neo-Cossacks see themselves as protectors of the ethnic purity of the territory given to them more than 200 years ago by Catherine the Great. ${ }^{132}$ Acting at the behest of the regional authorities, Cossack units have conducted thousands of violent nighttime raids and passport checks (proverki pasportnogo rezhima) on Meskhetian Turks over the last fifteen years to intimidate them and force them to leave the territory. ${ }^{133}$ For example, in May 2001, busloads of Cossack paramilitaries arrived in the region's Krymsk district "dressed in camouflage, carrying batons, and gas pistols," rounded up dozens of Meskhetian men for so-called passport checks at a police station and brutally beat them. ${ }^{134}$ In a disturbing trend, Krasnodar's Cossacks have become a model for law enforcement across the rest of Russia. In the spring of 2005, President Putin signed into law a bill granting Cossacks across Russia the right to bear arms and assist the police in "crime-fighting." 135

One Meskhetian Turk leader now living in the United States described the persecution the group endures on a daily basis:

You wake up in the morning and you are immediately afraid. You not only fear going out into the street, but also worry about being visited by the police, or [C]ossack groups, who do nothing but demand bribes and harass you.... You try to leave home as infrequently as possible. When you must go out to shop, or for some other task, you always worry about being stopped.... The authorities do not accept our Soviet-era documents. They say that we must have Russian documents. When we try to explain the reasons that we don't have proper documents, they do not care. Their reply is, "either go away, or die . ..."136

The desperation of the Meskhetian Turks reached a zenith in June 2002 when the regional authorities banned Meskhetian Turks from leasing and cultivating land. Left with virtually no income, approximately forty

130. See UCSJ Russian Regional RePORT 200I, supra note 70 (citing Municipal Krasnodar TV and Radio Company, Jan. 31, 2001; National News Service, Summary of Kubanskie Novosti, Feb. 16, 2001).

131. Id. (citing Russian newspaper /zvestiya, Feb. 27 2001).

132. Rodriguez, supra note 129.

133. Id.

134. Julie A. Corwin, Cossacks Conduct New Pogroms, RFE/RL Newsline, May 11, 2001, available at http://www.rferl.org/newsline/2001/05/5-NOT/not-1 10501 asp\#archive.

135. Robert Parsons, Cossack Revival Gathers Momentum, RFE/RL NewsLine, May 5, 2005, available at http://www.rferl.org/features/features_Article.aspx?m=05\&y=2005\&id=CB895A9A-04994975-AD2F-CA45534A7D68.

136. MESKhETIAN TURKS, supra note 37 , at 10. 
Meskhetian Turks staged a ten-day hunger strike and only agreed to suspend the strike when President Vladimir Putin pledged he would appoint a commission to investigate the continuing human rights violations in Krasnodar. ${ }^{137}$

The worsening human rights situation of the Meskhetian Turks in Krasnodar Krai over the past fifteen years and the Russian government's unwillingness to ensure the recognition of Meskhetian Turks' citizenship rights makes clear that the goal of integration is far from a durable solution to the current crisis. Just south of Krasnodar's border, Georgia continues to shirk its responsibility to repatriate voluntarily Meskhetian Turks who have not been allowed to return their homeland since the deportation in 1944.

III

\section{Repatriation: Georgia's Unfulfilled Promises}

Since the collapse of the Soviet Union, the issue of repatriation as a durable solution for the Meskhetian Turks has steadily gained international attention. For most of the last decade, international actors focused more of their efforts on repatriation to Georgia rather than on ending the human rights abuses experienced by Meskhetian Turks living in Russia's Krasnodar region. ${ }^{138}$ Several international organizations, including the Council of Europe, the Organization for Security and Cooperation in Europe (OSCE), the United Nations High Commissioner for Refugees (UNHCR), and the International Organization for Migration (IOM) have actively engaged the Meskhetian crisis. In 1996, these organizations, along with representatives of the Meskhetian Turks, formally recognized the group's voluntary right of return at a conference on regional migration organized by the Forced Migration Project of the Open Society Institute. While the conference resulted in few concrete results, it succeeded in raising the profile of the Meskhetian Turks to an international issue of human rights and security. ${ }^{139}$

Upon joining the Council of Europe in April 1999, Georgia assumed the obligation to:

[A]dopt, within two years after its accession, a legal framework permitting repatriation and integration, including the right to

137. Hunger Strike Continues in Krasnodar Krai, Three Hospitalized, RFE/RL NewSLINE, July 2, 2002, available at http://www.rferl.org/newsline/2002/07/020702.asp\#archive.

138. For a discussion on the role of international organizations, see Indra Oeverland, International Organisations, Regional Politics and the Meskhetian Turks, in ECMI: MESKHETIAN TURKs BETWEEN INTEGRATION AND RESETTLEMENT (forthcoming 2006) (on file with author).

139. Also, in 1998 and 1999, the OSCE High Commissioner on National Minorities (HCNM) organized consultations in the Hague and Vienna between the representatives of the post-Soviet governments affected, international organizations, and the Meskhetian Turks themselves to explore and find solutions to the crisis. See Forced Migration Monitor, Chairman's Statement From Vienna Meeting on Meskhetian Turk Issues, May 1999, No. 29, available at http://www.osi.hw/ fmp/html/may 1999.html\#vienna. 
Georgian nationality, for the Meskhetian population deported by the Soviet regime... to begin the process of repatriation and integration within three years after its accession and complete the process of repatriation of the Meskhetian population within twelve years after its accession. ${ }^{140}$

Over the course of the last decade, however, Georgian authorities have done little to move towards a genuine repatriation effort, with many high-ranking government officials and members of parliament openly stating their opposition to the return of the Meskhetian Turks. ${ }^{141}$ Opponents to repatriation have averred that it is impossible to accept Meskhetian Turks while the country still struggles to cope with the hundreds of thousands of refugees produced by two other regional interethnic conflicts in Abkhazia and South Ossetia. ${ }^{142}$ In addition, politicians playing on nationalist sympathies and xenophobia cite the risk that the Muslim group's return could spark clashes with the Christian Armenians living near their historical villages in Samtskhe-Javakheti. ${ }^{143}$

Acting little better than their counterparts in Krasnodar Krai, since 1999 Georgian leaders have repeatedly presented unrealistic and even discriminatory draft laws to parliament on Meskhetian Turk repatriation. ${ }^{144}$ For example, earlier versions of a draft repatriation law treated Meskhetian Turks as ordinary migrants, calling for them to adopt Georgian surnames. ${ }^{145}$ They also established a very complicated procedure of resettlement, with re-settler status itself guaranteeing no rights at all. ${ }^{146}$ Since the Rose Revolution of November 2003-a successive wave of protests against corrupt parliamentary elections which forced a peaceful coup d'état of Eduard Shevardnadze's government and brought a group of Western-oriented, young reformers to power-Georgia has taken some concrete steps to comply with its Counsel of Europe obligations. ${ }^{147}$ In a largely symbolic act the government sponsored the return of six Meskhetian Turks families from Azerbaijan to the Gori district in April

140. See Comn'n on Pol. Affairs, Georgia's Application for Membership of the Council of Europe, Opinion No. 209 (1999), available at http://portal.coe.ge/index.php?lan=en\&id=geoeu\&sub=3.

141. Sumbadze, supra note 27, at 53-63.

142. Fati Mamiashvili, Cool Welcome for Meskhetians, INSTITUTE OF WAR AND PEACE REPORTING: CAUCASUS REPORTING SERviCE, No. 315, Nov. 23, 2005, available at http://www.iwpr.net [hereinafter Cool Welcome for Meskhetians].

143. Id.

144. Email from Emil Adelkhanov, Chairman, Caucasian Institute for Peace, Development, and Democracy (CIPDD) (Tbilisi, Geor.) (Dec. 3, 2003) (on file with author).

145. Id.

146. Id.

147. For example, the author participated in a May 2005 conference organized by Georgia's State Minister for Conflict Resolution, Giorgi Khaindrava devoted to discuss the issue of Meskhetian Turks' repatriation to Georgia. 
2006. ${ }^{148}$ At the time of this Comment's publishing, however, none of the families selected for repatriation from Azerbaijan have yet been permitted to do so. Part of President Mikheil Saakashvili's overall strategy to integrate into Euro-Atlantic institutions, the parliament is currently working on the passage of a new law on repatriation for the Meskhetian Turks. ${ }^{149}$ Whether the new law on repatriation will adequately protect Meskhetian Turk repatriates and respect their right to acquire Georgian citizenship while allowing them to preserve their cultural identity remains to be seen.

Despite these earnest improvements, there are still important causes for concern. Georgian officials continue to view a repatriation effort as a political rather than legal obligation. In support of this claim, they argue that (1) Meskhetian Turks have no right to repatriate to a country that did not formally exist at the time of their deportation; and (2) even if this right exists, the Russian Federation is the legal successor state to the Soviet Union and thus solely responsible for the crimes of Stalin's regime. ${ }^{150}$ These arguments are addressed in turn.

\section{A. A Right to Return to One's Own Country}

The right to return to one's own country is considered customary international law and is widely recognized in international and regional instruments on human rights. ${ }^{151}$ In the context of state dissolution, and specifically, the collapse of the USSR, the term "country of origin" becomes problematic. Indeed, Stalin and the Soviet government deported the Meskhetian Turks from the Georgian Soviet Socialist Republic within the borders of the Soviet Union in 1944. Therefore, since the country of origin, the Soviet Union, had not existed since 1991, where do Meskhetian Turks have a right to return? Can they claim Georgia as their country of origin, even though Georgia did not exist as an independent country at the time of their deportation?

While experts traditionally agreed that the beneficiaries of the right to return must be citizens of their state of origin, differing views have developed in the last decade. This controversy stems from the fact that universal legal instruments recognize a right to return to one's own country, while regional instruments stipulate that "no one [should] be

148. Return of Meskhetian Turk Families to Georgia Begins, (BBC Worldwide Monitoring International Reports television broadcast Apr. 24, 2006), available at www.lexisnexis.com (citing Georgian news agency Kavkas-Press).

149. Cool Welcome for Meskhetians, supra note 142. Experts from the Council of Europe, human rights groups, some Meskhetian Turk organizations are consulting drafters of the law, which is tentatively entitled "On the Repatriation of Persons Deported from Georgia in the Forties in the Twentieth Century by the Soviet Regime."

150. Id.

151. See State Building, Citizenship, and Statelessness, Forced Migration Projects SpeCial REPORT (Open Socicty Institute), May 1997, at 2. 
deprived from the right to enter the territory of the state of which he is a national." "52 The Committee of Experts of the Council of Europe "considers the universal wording as wider in scope than that of the Fourth Protocol of the 1950 European Human Rights Convention, and to include not only nationals, but stateless persons and nationals of another state who have close ties with the country concerned as well." 153 Similarly, the final declaration adopted by the Uppsala international colloquium states that "a person's 'country' is that to which he is connected by a reasonable combination of such relevant criteria as race, religion, language, ancestry, birth, and prolonged domicile." 154

Recent practice shows that habitual place of residence-a criterion states may consider as proof of a person's attachment to a territory ${ }^{155}$ - is also important, and sometimes sufficient, to determine the country of origin. ${ }^{156}$ According to this reasoning, a formal link of nationality is not necessary for repatriation. To reduce the problem of statelessness, the UN International Law Commission has suggested that states consider not only a person's place of habitual residence, but also "any other appropriate connection with the successor state" to determine a link of nationality. ${ }^{157}$ This refers to the norm that states must take account of an individual's "genuine and effective link" with the territory, a broader concept of attachment to a state, initially developed in the Nottebohm Case ${ }^{158}$ in the World Court. In its discussion of nationality attribution following state succession, Article 18 of the 1997 European Convention on Nationality advocates resolution of this issue through treaty, and by way of analysis of

152. Protocol No. 4 to the European Convention for the Protection of Human Rights and Fundamental Freedoms, Securing Certain Rights and Freedoms Other Than Those Already Included in the Convention and in the Protocol Thereto art. 3, Sept. 16, 1963, C.E.T.S. No. 46, available at http://conventions.coe.int/Treaty/en/Treaties/Html/046.htm; see also American Convention on Human Rights art. 22(5), Nov. 22, 1969, 1144 U.N.T.S. 123; see e.g. African Charter on Human and Peoples' Rights art. 12(2), June 27, 1981, 1520 U.N.T.S. 217. The terms "national" or "nationality" are equivalent to "citizen" or "citizenship" in international law.

153. M.Y.A. Zieck, Voluntary Repatriation: An Analysis of the Refugee's Right to Return to His Own Country, 44 Austrian J. of Pub. \& INT'L L. 137, 144, (1992) (emphasis added).

154. An important international colloquium on "the right to leave and retum" took place in Uppsala, Sweden in 1972. This as one of the first attempts to provide the necessary procedural and substantive guidelines on the issue. The text of the final declaration can be found in HuRST HaNNUM, The Right to Leave and Return in International Law and Practice 58 (1987).

155. logna-Prat, Michel, Nationality and Statelessness Issues in the Newly Independent States, in The Problem of Refugees in Light of Contemporary International Law issues 28 (Vera Gowland-Debbas ed., 1996).

156. For examplc, see Dayton Agreement on Implementing the Federation of Bosnia and Herzegovina, Dec. 14, 1996, 7 Dep't St. Dispa TCh I, 35 I.L.M. 170 (1996); see also U.N.G.A., Int' L. Comm'n., Nationality in Relation to the Succession of States, U.N. Doc. A/54/10 (1999) [hereinafter Nationality in Relation to the Succession of States].

157. Nationality in Relation to the Succession of States, supra note 156

158. Nottcbohm Case (Liech. v. Guat.), 1955 I.C.J. 4, 22-23 (Apr. 6) (holding that "nationality is a legal bond having as its basis a social fact of attachment, a genuine connection of existence, interest, and sentiments, together with the existence of reciprocal rights and duties."). 
the "genuine and effective link, habitual residence right of option, and territorial origin." 159 Territorial origin includes that of the person, where $\mathrm{s} / \mathrm{he}$ was born or where his or her parents or grandparents were born. ${ }^{160}$ These international standards suggest that the Meskhetian Turks' links of nationality with Georgia allow for their right of repatriation.

Because the state originally responsible for the Meskhetian Turks' deportation has disappeared, who is presently responsible for restoring their rights? The majority view is that because the Russian Federation is the official successor state to the Soviet Union, it must assume responsibility for the crimes attributed to the Soviet Union. ${ }^{161}$ Does this mean that Georgia has no legal obligations towards the Meskhetian Turks? Even without a specific agreement on the issue, Georgia is bound by human rights law, which provides for the right to return.

In contravention of these norms, Georgia refuses to recognize the Meskhetian Turks' link of nationality on the ground that they were not Georgian residents in 1991, even though this is a direct result of their deportation and the denial of their right to return in the years leading up to independence. Using the pretext of the lack of Georgian citizenship to refuse Meskhetian Turks entry onto Georgian territory, the government is carrying on an illicit international act, namely the deportation. Under the Draft Articles on Responsibility of States for Internationally Wrongful Acts, by facilitating the Meskhetian Turks' continuing statelessness, Georgia may be viewed as an accessory to its perpetration. ${ }^{162}$

However, even if Georgia does not recognize these links and refuses to grant them the right to return, the Meskhetian Turks in Krasnodar must not remain stateless. It is contrary to human rights law and the principles concerning the reduction of statelessness for Russia to refuse them citizenship on the ground that their genuine link of nationality is only with Georgia. The Meskhetian Turks must have a right to choose between Georgian or Russian citizenship, without discrimination. ${ }^{163}$ Indeed, Moscow and Krasnodar must not use Georgia's failure to repatriate the Meskhetian Turks as a foil for their own unwillingness to handle the problems of xenophobia within their own jurisdiction.

159. See European Convention on Nationality, June 11, 1997, C.E.T.S. no. 166, available at http://conventions.coe.int/Treaty/en/Treaties/Html/166.htm; See also Carol A. Batchelor, Statelessness and the Problem of Resolving Nationality Status, 10 INT'L J. Refugee L. 156, 163 \& n. 19 (1998)

160. Id.

161. Rein Mullerson, The Continuity and Succession of States, by Reference to the Former USSR and Yugoslavia, 42 1NT'L \& CoMP. L. Q. 473, 473-93 (1993).

162. See U.N.G.A., Int' L. Comm'n., Draft Articles on Responsibility of States for Internationally Wrongful Acts art. 4, U.N. GAOR, 56th Sess., Supp. No. 10, at 84, U.N. Doc. A/56/10 (2001).

163. The right of option is also mentioned by the Nationality in Relation to the Succession of States. Nationality in Relation to the Succession of States, supra note Error! Bookmark not defined., at art. 15 ("States concerned shall not deny persons concerned the right to retain or acquire nationality or the right of option upon the suecession of states by discrimination on any ground."). 
As Part's II and III have suggested, Russia's failure to improve human rights in Krasnodar and Georgia's unwillingness or inability to facilitate repatriation have made integration and repatriation unlikely solutions to the plight of the Meskhetian Turks. After years without a durable solution, and in response to the intensification of deportations, beatings and discrimination in Krasnodar Krai over the period of 19892004, the U.S. government addressed the ongoing crisis and proposed a resettlement program for the Meskhetian Turks of Krasnodar Krai. Addressing several factors that contributed to the designation of Meskhetian Turks as refugees of special humanitarian concern, Part IV draws on the successes and challenges of the Meskhetian Turk resettlement initiative to explore the potentiaIs of the U.S. refugee program as a tool for improving individual lives while also encouraging troubled regions to respect human rights.

\section{IV}

\section{RESETTLEMENT:}

\section{The United States Meskhetian Turk Refugee Program}

For the Meskhetian Turks, resettlement may be the best, and perhaps only, durable solution. According to the U.S. State Department, "[v]oluntary repatriation is also not an option for Meskhetian Turks and other de facto stateless populations. With the dissolution of the Soviet Union, their former homes are now in new countries with new citizenship laws that do not currently provide them with any legal status." ${ }^{64}$ Due to the limited number of individuals who are able to benefit from it, resettlement is always an extraordinary remedy for the refugee. The United States accepts far more refugees for permanent resettlement every year than any other country in the world. ${ }^{165}$

The case of the Meskhetian Turks illuminates many important questions about the potential of resettlement to improve dramatically the lives of individuals and the rights of minorities as a whole in the Krasnodar region. Moreover, as one of the largest single refugee groups admitted to the U.S. since the near-shutdown of the refugee program after the September 11 attacks, it also illustrates the efficacy of U.S. resettlement as a foreign policy tool. ${ }^{166}$ The example of the Meskhetian Turks' successful

164. Proposed Refugee Admissions for FY 2006, supra note 7, (manuscript at 30).

165. In 2002, the United States admitted 26,300 refugees for resettlement. In comparison, Canada admitted 10,400, Norway admitted I,200, Sweden admitted I,000, New Zealand admitted 670, Finland admitted 570, Denmark admitted 490, the Netherlands admitted 160, and Ireland admitted 23. UNHCR, Refugees by Numbers 2003, available at http://www.unhcr.org/cgi-bin/texis/vtx/basics/ opendoc.pdf?tbl=BASICS\&id=3c149b007.

166. As part of its response to the September 1 I attacks, the United States immediately suspended refugee resettlement for several months. See Newman, supra note 5; see also Marisa Silenzi Cianciarulo, The W Visa: A Legislative Proposal for Female and Child Refugees Trapped in a PostSeptember $1 /$ World, I7 YaLE J.L. \& Feminism 459, 470 (2005) (noting that in fiscal year 2002, the 
initial experience in the United States demonstrates resettlement should be expanded in the post-September 11 context to sustain the United States' role as a leader in humanitarian affairs and human rights.

To provide context to the current Meskhetian Turk resettlement program, this section begins by examining factors that contributed to the designation of Meskhetian Turks as refugees of special humanitarian concern. ${ }^{167}$ It focuses on the changing nature of the relatively unknown U.S. overseas refugee program and discusses the successful lobbying effort mounted by human rights activists on behalf of the Meskhetian Turks. Second, it is important to examine the parameters of eligibility for such a transnational community. As a matter of policy, how does one effectively draw lines to determine which Meskhetian Turks are eligible for resettlement? And, what is to become of similarly situated ethnic groups such as Hemshins and Batumi Kurds who were also victims of deportation and are now perceived as Meskhetian Turks by the Krasnodar authorities and Cossack militias? Indeed, resettlement should not inadvertently endanger the rights of those it aims to protect and must be accompanied by a robust human rights policy on the ground to avoid encouraging local authorities to pursue further campaigns for the expulsion of undesired migrants. Finally, this section attempts to encourage the further use of resettlement for similarly situated groups by drawing on the experiences and insights of newly resettled American Meskhetian Turks.

\section{A. Overseas Admissions and Refugees of Special Humanitarian Concern}

Americans commonly perceive a refugee to be an individual who has received asylum on political or religious grounds in an affirmative or removal proceeding in a court of law, a form of relief which is reactive, as it is only available to individual applicants once they have reached the country. By contrast, the relatively little-known U.S. Refugee Program admits tens of thousands of "refugees of special humanitarian concern"168 directly from other countries every year. ${ }^{169}$ In 1980, Congress passed the Refugee Act, thereby creating the U.S. Refugee Program, which strengthened the United States' historic policy of aiding individuals fleeing persecution in their homelands and codified the current framework for refugee admissions. ${ }^{170}$

\footnotetext{
United States fell short of its 70,000-person refugee admission ceiling by 42,971, and fiscal year 2003 saw a shortfall of 17,125); see e.g. U. S. Dep't of State, Bureau of Population, RefugeEs and Migration, Summary of Refugee Admissions: FisCal Year 2003 (2003), available at http:/www.state.gov/documents/organization/38023.pdf [hereinafter U.S., Refugee Admissions 2003].

167. 1mmigration and Nationality Act, 8 U.S.C. $\$ 1157(a)(3)(2000)$.

168. Id.

169. Daniel J. Steinbock, The Qualities of Mercy:Maximizing the Impact of U.S. Refugee Resettlement, 36 U. MiCH. J.L. REFORM 951, 952 (2003).

170. U.S. Dep't of State et al., Proposed Refugee Admissions for FY 2005-Report to THE CONGRESS 9 (2004), available at http://www.state.gov/documents/organization/36228.pdf [hereinafter Proposed Refugee Admissions fOR FY 2005] (DHS/USCIS Refugee Adjudications
} 
To resettle in the United States through this program, refugees must undergo a rigorous screening process administered by the State Department Bureau of Populations, Refugees and Migration (PRM) in conjunction with the Department of Homeland Security (DHS) ${ }^{171}$ and the Office of Refugee Resettlement of the Department of Health and Human Services (ORR/DHHS). ${ }^{172}$ Applicants for admission to the United States must (1) meet the definition of a refugee, ${ }^{173}$ (2) be among those refugees whom the President determines to be of special humanitarian concern, ${ }^{174}$ (3) be otherwise admissible under U.S. law, ${ }^{175}$ and (4) not be "firmly resettled"176 in another country. ${ }^{177}$

In addition to relying on the above criteria to screen resettlement applicants, the United States employs a priority system to determine in what order to accept applicants who meet the basic eligibility criteria. Pursuant to 8 U.S.C. $\S 1157(\mathrm{e})$, the President submits an annual report to Congress detailing his recommendations for refugee admissions. ${ }^{178}$ The report is a core part of an annual consultative process involving the presidential administration, Congress, representatives of state and local

Section 207 of the INA grants the Secretary of the Department of Homeland Security (DHS) authority to admit, at his discretion, any refugee who is not "firmly resettled" in a third country, who is "determined to be of special humanitarian concern," and who is "admissible [to the Unitcd States] ... as an immigrant. The authority to determine eligibility for refugee status has been delegated to U.S. Citizenship and Immigration Services (USCIS)).

I7I. Formerly known as the Immigration and Naturalization Service (INS).

172. See UNHCR, Resettlement Handbook and Country Chapters the UNITED STATES OF AMERICA 4-5 (2004), http://www.unhcr.org/cgi-bin/texis/vtx/home/ opendoc.pdf?tbl=PROTECTION\&page=PROTECT\&id=3c5e5a764 [hereinafter UNHCR, Country Chapter: USA] (describing resettlement policies and procedures in the United States).

173. 8 U.S.C. $\&$ I101(a)(42) (2000) ("[A]ny person who is outside any country of such person's nationality or, in the case of a person having no nationality, is outside any country in which such person last habitually resided, and who is unable or unwilling to return to, and is unable or unwilling to avail himself or herself of the protection of, that country because of persecution or well-founded fear of perseeution on account of race, religion, nationality, membership in a particular social group, or political opinion ....").

174. 8 U.S.C. $\S 1157(a)(3)(2000)$.

I75. 8 U.S.C. $\$ 1182$ (2000) (classifying groups of aliens ineligible for visas or admission).

176. 8 U.S.C. $\S 1$ I $58(\mathrm{~b})(2)(\mathrm{A})(\mathrm{vi})(2000)$.

177. See UNHCR, CounTry ChAPTER: USA, supra note I72, at I (noting fivc key criteria for refugee admission in U.S.).

178. A report must include:

(1) A description of the nature of the refugee situation. (2) A description of the number and allocation of the refugees to be admitted and an analysis of conditions within the countries from which they came. (3) A description of the proposed plans for their movement and resettlement and the estimated cost of their movement and resettlement. (4) An analysis of the anticipated social, economic, and demographic impact of their admission to the Unitcd States. (5) A description of the extent to which other countries will admit and assist in the resettlement of such refugees. (6) An analysis of the impact of the participation of the United States in the resettlement of such refugees on the foreign policy interests of the United States. (7) Such additional information as may be appropriate or requestcd by such members. 8 U.S.C. \$ $1157(\mathrm{e})(2000)$. 
governments, public interest groups, and NGOs. ${ }^{179}$ The end result of this process is the priority system for refugee resettlement.

The United States gives the highest priority to refugees whom UNHCR or a U.S. Embassy refers for resettlement due to urgent humanitarian concerns. ${ }^{180}$ These individuals receive Priority One, or P-1, status. Priority One refugees generally include those who face compelling security concerns in the country of first asylum, victims of torture or violence, at-risk women, persons in urgent need of medical care, and persons who have suffered persecution because of their political, religious, or human rights activities. ${ }^{181}$ Prior to acceptance for resettlement, referrals must still establish past persecution or a well-founded fear of future persecution in the country from which they fled. ${ }^{182}$

In addition to P-1 processing, the United States designates groups of special humanitarian concern ${ }^{183}$ for Priority Two, or P-2, processing, and relatives of nationals of certain countries for Priority Three, or P-3, processing. The P-2 category, which encompasses the Krasnodar Meskhetian Turks, includes specific groups (within certain nationalities, clans, or ethnic groups) identified by the Department of State in consultation with non-governmental organizations, UNHCR, and other experts. ${ }^{184}$ In addition to the Meskhetian Turks in Russia, the Bush Administration identified a number of groups for P-2 resettleinent in fiscal year 2005, including human right activists in Cuba; Iranian members of religious minorities; Jews, Evangelical Christians, and certain members of Orthodox churches in the former Soviet Union identified in the Lautenberg Amendment; ${ }^{185}$ and Hmong in Thailand. ${ }^{186}$ Those selected are generally allowed to stay indefinitely, to adjust to permanent residence status, and ultimately to become American citizens.

Applicants for resettlement falling within the priorities of the relevant nationality or region proceed through several levels of adjudication to determine eligibility for admission under sections 110I(a)(42) and 207 of

179. See UNCHR, Country ChAPTER: USA, supra note 172, at 2 (noting key actors the President consults with before creating U.S. refugee policy).

180. Proposed Refugee Admissions For FY 2005, supra note 170, at 7 (discussing U.S. policy to take refugees with most urgent need with higher priority).

181. See UNHCR, CounTry Chapter: USA, supra note 172, at 2 (stating which persons are defined as P-1 in the U.S.)

182. See id. (discussing well founded fear interview, the process in which refugees discuss their fear about returning to their native countries).

183. Immigration and Nationality Act \$207(a)(3), 8 U.S.C. §1157(a)(3) (2000); See also Proposed Refugee Admissions for Fiscal Year 2006, supra note 7 (manuscript at 19).

184. The P-2 designation also includes Hmong Lao at Wat Tham Krabok in Thailand, Iranian religious minorities, primarily in Austria, Vietnamese in the Philippines, Somali Benadir in Kenya, Burundians in Tanzania, Somali in Uganda, and Liberian groups in Ghana and Guinea. Id.

185. Foreign Operations, Export Financing, and Related Programs Appropriations Act, Pub. L. No. 101-167, § 599D, 103 Stat. 1261 (1989), as amended.

186. Id. at 8 
the Immigration and Nationality Act. ${ }^{187}$ In the case of the Krasnodar Meskhetian Turks, applicants are eligible to apply for the program directly to an overseas processing entity (OPE) ${ }^{188}$ which prepares an initial application for refugee status. Applicants who appear to have suffered persecution or to have a well-founded fear of future persecution ${ }^{189}$ and who otherwise fall within the United States' resettlement priorities meet with a U.S. immigration official to determine whether they qualify for admission as refugees. ${ }^{190}$ And while they fall outside the scope of the Lautenberg Amendment, Meskhetian Turks, like Jews, Evangelical Christians, and certain members of the Ukrainian Catholic or Ukrainian Orthodox Churches of the Former Soviet Union, benefit from a more relaxed evidentiary burden than in conventional asylum adjudications. ${ }^{191}$

Once the immigration authorities approve an applicant for resettlement, the applicant must undergo a medical examination and security checks before travel arrangements to the United States can be made. Upon admission, refugees are authorized for employment. ${ }^{192}$ After one year, a refugee is eligible to apply for adjustment of status to lawful permanent resident. ${ }^{193}$ Five years after admission, a refugee who has been

187. Id.

188. In this case, the OPE is the International Organization for Migration (1OM) which has both Moscow and local Krasnodar offices.

189. See Matter of Mogharabbi, 19 I. \& N. 439, 446, 1987 BIA LEXIS 5 (Bd. Immigr. App. 1987) (interim decision) (holding that an individual's fear of persecution is well-founded if "( $\mathrm{I}$ )[he or she] possesses belief or characteristic a persecutor seeks to ovcrcome in others by means of punishment of some sort; (2) the persecutor is already aware, or could ... become aware, that the [individual] possesses this belief or characteristic; (3) the persecutor has the capability of punishing the [individual]; and (4) the pcrsecutor has the inclination to punish the [person]") (quoting Matter of Acosta, $191 . \& \mathrm{~N}$. Dec. 21 I, 226 (Bd. Immigr. App. 1985)).

190. See 8 C.F.R. $\S 208.13$ (a) (2005) ("The testimony of the applicant, if credible, may be sufficient to sustain the burden of proof without corroboration."). The situation of refugees often makes it difficult for them to provide documentary or third party testimonial corroboration of their claims, but U.S. regulations governing asylum, in conformity with U.N. recommendations, specify that an applicant's credible testimony is sufficient to establish eligibility. Id; see also UNHCR, Handbook on Procedures and Criteria for Determining Refugee Status Under the 1951 Convention and the 1967 Protocol Relating to the Status of Refugees, HCR/PP/4/Eng/REV.1 P 196 (1992), http://wwwl lumn.edu/humanrts/instree/refugeehandbook.pdf [hereinafter UNHCR, Handbook on Procedures and Criteria] ("In most cases a person fleeing from persecution will have arrived with the barest necessities and very frequently even without [] documents.... [I]f the applicant's account appears credible, he [or she] should, unless there are good reasons to the contrary, be given the benefit of the doubt.").

191. Id. A USCIS officer conducts a face-to-face interview of each applicant. The interview is designed to elicit information about the applicant's claim for refugee status. The officer asks why the applicant seeks departure from his or her country of nationality and about problems or fears the applicant may have had or will have if returned to the country of nationality. In the in-country processing programs, the officer's questions focus on problems the applicant has had or fears having if he or she remains in his/her country of nationality. In the process, the officer considers background information concerning conditions in the country of nationality and assesses the applicant's credibility and claim. Id.

192. Id.

193. Id. 
granted lawful permanent resident status is eligible to apply for citizenship. ${ }^{194}$

\section{B. An Unlikely Lobby}

Before 2004, only a handful of Meskhetian Turks lived in the United States. ${ }^{195}$ The few that resided in the country came not as part of any organized collective migration but rather individually on student or work visas or as family or employer-sponsored immigrants. Unlike other refugee groups such as the Cubans, Vietnamese, or Soviet Jews, the Meskhetian Turks did not have a well-formed constituency or lobby to promote the cause of their resettlement. In fact, many in Washington's refugee and policy circles had never heard of the Meskhetian Turks when President Bush designated them as refugees of special humanitarian concern in late 2003. Out of the worldwide population of over 17 million refugees, ${ }^{196}$ how and why did the Meskhetian Turks receive such a powerful and extraordinary remedy from the U.S. government?

While it would be beyond the scope of the present Comment to address this question fully, part of the answer lies in a number of factors that are worth noting here. As the previous sections have suggested, the failure of the Russian authorities to recognize the citizenship of the Meskhetian Turks in Krasnodar Krai and Georgia's refusal to meet its obligations to repatriate the group in good faith alerted the rest of the international community, including U.S. refugee officials, to the plight of a long-suffering population which had experienced decades of displacement.

Beginning in the mid-1990s, UNHCR began reporting on the problems of Meskhetian Turks in Krasnodar Krai to governments and other international organizations at regular intervals. ${ }^{197}$ Since that time, U.S. refugee officials at PRM and the Immigration and Naturalization Services (INS)-later the Department of Homeland Security (DHS)-were involved in discussions about the possible resettlement of Meskhetian Turks. ${ }^{198}$ However, while some at UNHCR pushed for the group's resettlement to third countries, the agency's dominant position was that the Russian government should ensure that the Krasnodar authorities recognize and treat the Meskhetian Turks as citizens in accordance with Russian law. ${ }^{199}$

\footnotetext{
194. Id.

195. Newman, supra note 5 (featuring an interview with a Meskhetian Turk woman who was able to immigrate to the United States with her husband and her father in 1992 and who believed that the three of them were the only Meskhetian Turks to make it to the United States).

196. This tally of the current worldwide population of refugees comes from the UNHCR's Global ApPeal 2005 Report. Facts AND Figures, (2005), available at http://www.unhcr.org/cgi$\mathrm{bin} / \mathrm{texis} / \mathrm{vtx} / \mathrm{publ} /$ opendoc.pdf?id=41 ab28c50\&tbl=PUBL.

197. Interview with Bohdan Nahajlo, UNHCR Azerbaijan Country Director, in Flensburg, Germany (Sept. 2004) (on file with author).

198. Interview with Moscow-based IOM official and Maureen Greenwood, Amnesty International (Oct. 2005) (on file with author).

199. Id.; Interview with UNHCR Officer, in Baltimore, Md. (Oct. 2002) (on file with author).
} 
The U.S. government along with the other two international organizations involved in resolving the Meskhetian crisis, the Council of Europe and the Organization for Security and Cooperation in Europe (OSCE), shared this view for the next several years. The institutional stance was that the Meskhetian Turk situation in Krasnodar was not a traditional refugee issue; rather, it was about the enforcement of the rule of law and human rights in Russia and about battling the Krasnodar authorities' pervasive xenophobia. ${ }^{200}$

Beyond the corridors of embassies and international agencies, a transnational advocacy network between grassroots human rights groups in Russia and the United States was also taking shape. Indeed, the Meskhetian Turks of Krasnodar found U.S. backing among unlikely supporters. Instead of Turkish or Muslim advocates, American Jewish human rights and refugee organizations such as the Hebrew Immigrant Aid Society (HIAS) and the Union of Councils for Jews in the Former Soviet Union (UCSJ) called attention to the situation in Krasnodar Krai ${ }^{201}$ While these groups initially knew little about the Meskhetian Turks, they were uniquely positioned to learn about the plight of this obscure people by virtue of having monitored the situation for Jews in the former Soviet Union and especially in Russia's Krasnodar region throughout the 1990s. ${ }^{202}$ By using anti-Semitism and anti-minority rhetoric as a part of his campaign to rebuild a neo-Cossack movement, Governor Kondratenko inadvertently had put Krasnodar and the Meskhetian Turk issue on the map. ${ }^{203}$

Gradually, several other key players within the U.S. human rights community joined the effort to address the issue. The late Arthur Helton, a prominent refugee expert who headed the Open Society Institute's Forced Migration Project, helped organize a CIS Conference on Migration for the Newly Independent States in 1996 where the Meskhetian issue was first seriously raised in a diplomatic setting. ${ }^{204}$ Between 1996 and 2001, as conditions for the Meskhetian Turks worsened, Alexander Osipov, a

200. Interview with UNHCR Officer, in Baltimore, Md. (Oct. 2002) (on file with author)

201. See Union of Councils for Jews in The Former Soviet Union (USCJ), More Ethnic VIOLENCE IN KRASNODAR KRAY, May 1, 2003, available at http://www.fsumonitor.com/stories 050103Russia.shtml; see also UCSJ RUSSIAN REGIONAL REPORT 200I, supra note 70; see, e.g., Refugee Council U.S.A., U.S. Refugee Admissions Program for Fiscal Years 2004 and 2005 , Sept. 2004, available at http:/www.refugeecouncilusa.org/2004RCUSAinterim-w.pdf. The author of this piece represented the Union of Councils for Soviet Jews (UCSJ) in Krasnodar during the period 2000-2001.

202. Celestine Bohlen, Where Russians Are Hurting, Racism Takes Root, N.Y. Trmes, Nov. 15, 1998 , at 3.

203. Id.; See also Union of Councils for Soviet Jews (USCJ), available at www.fsumonitor.com (last visited May 1,2006 ) (providing access to early reports on the situation of the Meskhetian Turks as well as the problem of anti-Semitism in Krasnodar Krai).

204. Posting of Paulette Layton to http://www.osi.hu/fmp/fmalert/0444.html (June 15, 1999, 16:17:26) (stating that up to one hundred representatives of local NGOs in CIS states were expected to attend the June 22-23, 1999 meeting in Geneva to discuss strategies for third-sector participation). 
researcher at Memorial-one of Russia's leading human rights organizations-published two groundbreaking monographs about the discrimination in Krasnodar Krai. ${ }^{205}$ Meanwhile, several local Krasnodar-based organizations, the Meskhetian Turks' own advocacy organization Vatan (Fatherland), and the Russian School of Peace began grassroots attempts to combat racism on the ground and appealed to the OSCE, the UNHCR, the Council of Europe, and the U.S. government for help. When Krasnodar Governor Tkachev openly called for the creation of deportation centers in 2002, this author appeared at a Radio Free Europe press conference about the impending expulsion of ethnic minorities. ${ }^{206}$ In 2003, Representative Christopher Smith, a strong advocate for refugee admissions and co-chairman of the Helsinki Commission, made an appeal on the floor of the House of Representatives to pressure President Putin about his record on dealing with the Meskhetian Turks. ${ }^{207}$ The persecution of Meskhetian Turks in Krasnodar had reached a zenith and was making its way into the headlines of the American press. ${ }^{208}$ In 2002, the Washington office of Amnesty International arranged for leading Krasnodar-based human rights activists, Tamara and Vadim Karastelev, to meet with American refugee officials and lawmakers on Capitol Hill to discuss the severity of the situation, which many acknowledge as the trigger for the current resettlement program. ${ }^{209}$

\section{Meskhetian Turks and the New Resettlement Paradigm}

Beyond the extraordinary efforts of dedicated individuals and human rights organizations, the choice of the Meskhetian Turks seems to be rooted in the changing nature of the U.S. Refugee Program. In a sense, the Meskhetian Turks are a harbinger for "a distinctively new era for refugee

\footnotetext{
205. See The Situation of the Meskhetian Turks, supra note 77.

206. Brink of Expulsion, supra note 89.

207. 112 CONG. REC. 149 (2003) (statement of Rep. Smith).

The second situation I want to briefly highlight concerns the plight of Meskhetian Turks in the Krasnodar Krai region ... these displaced individuals find themselves in a virtual no man's land, denied citizenship and permanent residency permits, as well as many other fundamental rights .... By not granting citizenship or providing permanent residency status, current Russian policy enables the discriminatory practices subjugating the rights of Meskhetian Turks in Krasnodar Krai to eontinue.... I urge him [President Putin] and Members of the State Duma to rectify the status of Meskhetian Turks and other stateless persons. Meanwhile, the Kremlin should intervene to ensure that Krasnodar Krai officials desist in their discriminatory treatment of the Meskhetian Turks until their status is normalized, as well as guarantee the proseeution of violent eriminals.
}

208. Susan B. Glasser, Immigrants Feeling Russians' Wrath:Paramilitary Groups Aid Crackdown by Nationalist Governor, WASH. PosT, June 12, 2002, at Al.

209. Interview with Vadim and Tamara Karastelev, in Krasnodar, Russ. (Aug. 2004); Interview with Moscow-based IOM Official and Maureen Greenwood, Amnesty lnternational (Oct. 2005 \& July 2001) (on file with author). 
resettlement." ${ }^{210}$ A brief history of the U.S. overseas refugee resettlement program helps illustrate this trajectory.

The United States began resettling refugees in 1948, starting with the Displaced Persons Act of that year, which covered post-war European refugees. ${ }^{211}$ Later legislation and administrative action during the $1950 \mathrm{~s}$ allowed persons fleeing Communist regimes to enter, largely from Hungary, Poland, Yugoslavia, and China. In the 1960s and 1970s, the United States welcomed Cubans to the United States. Beginning in 1975, the U.S. accepted large numbers of Vietnamese and then Lao and Cambodian refugees. ${ }^{212}$ These programs found their authority in legislation specific to a particular crisis, group, or time-period, or, on occasion, Presidential immigration power until the passage of the Refugee Act in $1980 .{ }^{213}$

Between 1975 and 2006, the United States accepted over 2.5 million overseas refugees, mostly from Indochina and the former Soviet Union. ${ }^{214}$ It has also provided more than 20 million dollars during the past nine years to expand UNHCR's resettlement infrastructure. ${ }^{215}$ By 2001, the United States had largely completed these massive and steady refugee flows. ${ }^{216}$ The Cold War had ended and many believed the U.S. Refugee Program was left without a raison d'etre. ${ }^{217}$ After the events of September 11, 2001, the sanctuary nearly closed due to heightened security concerns. One immediate outcome was that it became much harder to ensure the safety of U.S. refugee interviewers when they visited refugee encampments around the globe. While in 1992, approximately 142,000 refugees moved to the United States, in 2002 , admissions collapsed to 27,000 , rising to only 28,000 in $2003 .{ }^{218}$ Recognizing that the overseas admission program was at

210. David A. Martin, The United States Refugee admissions Program: Reforms for a NEw ERA OF REFUGEE RESETTLEMENT, available at http:/www.state.gov/documents/ organization/36495.pdf (last visited May 24, 2006) [hereinafter MARTiN].

211. See generally, Gil Loescher \& John A. Scanlan, Calculated Kindness: Refugees and America's Half-open Door, 1945 to the Present (1986).

212. Bill Ong Hing, Making and Remaking Asian America Through Immigration Policy 1850-1990, 121-38 (1993).

213. Refugee Act of 1980, Pub. L. No. 96-212, 94 Stat. 102 (1980) (codified as and amended at 8 U.S.C. $\S \S 1157-59(2000))$.

214. U.S. Dep't of State, Bureau of Population, Refugees, and Migration, Fact Sheet (Oct., 2005) (on file with author).

215. U.S. Dep't of State et al., Bureau of Population, Refugees and Migration, Proposed Refugee Admissions for FY 2003-Report to the Congress (2002), available at http://www.state.gov/g/prm/refadm/rls/rpts/2002/13892.htm.

216. David A. Martin, A New Era for U.S. Refugee Resettlement, 36 Colum. Hum. RTS. L. Rev. 299, 301 (2005); See also Donald Barnett, Out of Africa: Somali Bantu and the Paradigm Shift in Refugee Resettlement, Center for Immigration Studies, Oct. 2003, at 2 (on file with author).

217. MARTIN, supra note 210.

218. Newman, supra note 5. 
a crossroads, officials in the Bush administration recommitted to building back up the numbers while trying to prioritize security concerns. ${ }^{219}$

David Martin, a noted refugee expert, has characterized the changing priorities of the American resettlement program in the post-September 11 landscape: "we are extremely unlikely in this new century to find the United States or any other country willing to make a virtually open-ended commitment to resettlement of virtually all who escape a designated nation." ${ }^{.220}$ Instead:

[R]esettlement initiatives will be marked by the need to draw clear lines around the group to be admitted.... The quest will be for finite groups, and resettlement will work best if much solid work on identification and line-drawing can be completed before resettlement plans become known in the refugee camp or settlement. ${ }^{221}$

In addition to these guidelines, future resettlement initiatives will seek to avoid conducting overseas interviews in locations, which could endanger American asylum officers and ensure against admitting those individuals who could be threats to national security.

The Meskhetian Turks of Krasnodar Krai, a long-suffering group in urgent need of rescue, seem to satisfy all the criteria of this new resettlement paradigm. A small population of well-educated and relatively secular Muslims, they pose no terrorist threat. According to Ralston $\mathrm{H}$. Deffenbaugh $\mathrm{Jr}_{\mathrm{r}}$, president of the national Lutheran Immigration and Refugee Service, "[t]hey did not pose any sort of a security threat, not coming from a country or a group from which terrorists have sprung .... It was safe for U.S. interviewers to go there to interview them."'222 There were other plus factors. As with all refugees who resided in the authoritarian Soviet Union, Meskhetian Turks presented the unique advantage of possessing a good deal of personal identification documents. In addition, they were a relatively accessible population, geographically concentrated in one location, not a war zone, and hence easy for U.S. interviewers to reach.

\section{A "Finite" Group?}

Along with the advantages Meskhetian Turks bring with them, there are still always difficult decisions related to the question of who is eligible. When it was determined that Meskhetian Turks in Krasnodar should be offered resettlement, refugee officials designed specific criteria for

219. Felix Doligosa Jr., From Their Home Countries to Colo.; Refugee Numbers Rebounding After Big Post-9/11 Slide, Rocky Mountain News, Oct. 24, 2005, at 5A.

220. MARTIN, supra note 210 , at vi. (second emphasis added).

221. Id.

222. Gaiutra Bahadur, A Home in America, PHIL. Inquirer, Sept. 23, 2004, available at http://www.philly.com/mld/philly/news/9734723.htm (internal quotations omitted). 
eligibility. These criteria allowed refugee officials to draw lines around a "finite group" of Meskhetian Turks that would be targeted for resettlement. According to the program, a Meskhetian Turk applicant must:

1. Prove that he/she is an "ethnic Turk";

2. Demonstrate that he/she has resided in Krasnodar Krai before January 1,2004 and continues to reside there;

3. Have fled from Uzbekistan;

4. Have experienced difficulties "fully integrating" into the Russian Federation. ${ }^{223}$

According to the program criteria, the program would focus only on Meskhetian Turks who experienced persecution within Krasnodar Krai, and not on any other parts of the Russian Federation, other states in the former Soviet Union or Turkey.

A closer analysis of the program's eligibility criteria, however, reveals that this type of line-drawing implicates a host of difficulties for refugees like the Meskhetian Turks, who have become such a transnational group by virtue of the types of persecution they have suffered. In addition, the criteria themselves problematically exclude similarly situated groups who are part of the legitimate focus of the resettlement initiative.

First, the criterion that applicants prove they are "ethnic Turks" raises concerns the about the categorization of the group as well as the inclusiveness of the resettlement initiative. By classifying the group as "ethnic Turks," refugee officials unwittingly reinforce an already politicized ethnic terminology, which has been the subject of intense debate for decades among the larger Meskhetian people, the scholarly community, and international organizations about the group's Georgian and Turkish origins. ${ }^{224}$ While many Meskhetian Turks inside and outside Krasnodar self-identify as "Turks," others use labels such as "Meskhs," "Ahiska Turks," or simply "Meskhetian Turks" to identify themselves. ${ }^{225}$

More importantly, perhaps, this criterion fails to account for several smaller transnational groups who are, in many respects, identical to the Meskhetian Turks. Hemshins and Batumi Kurds, two groups who were deported along with the Meskhetian Turks from Southern Georgia in 1944, also fled Central Asia to Krasnodar due to anti-Meskhetian violence after 1989 and have similarly been subjected to persecution and statelessness by the Krasnodar authorities. ${ }^{226}$ While distinct from the Meskhetian Turks, the three Muslim peoples share many cultural characteristics with one another,

223. International Organization for Migration, Application Matcrials to U.S. Meskhetian Turk Resettlement Program collected in Krasnodar, Russia (July 2004) (on file with author).

224. For further discussion of the ideological debate over the ethnic identity of the Meskhetian Turks, see Transnational Minorities, supra note 24 , at 9.

225. Id.

226. For a discussion of the Hemshins and Batumi Kurds, see Steve Swerdlow, The Hemshins of Krasnodar Krai: Human Rights and the Struggle to Survive, in Hemshins (Hovann Simonian ed.) (forthcoming 2006). 
and all are perceived as "Turks" by the Krasnodar authorities, Cossack vigilantes, and the surrounding Slavic population. ${ }^{227}$ ln addition, many Hemshins and Batumi Kurds became active in the Vatan movement for the return to Georgia. Furthermore, many carry Soviet passports that include the designation of "Turk" in the fifth line for nationality. ${ }^{228}$ When initial discussions of the resettlement effort were opened in Krasnodar in 20032004, most Hemshin and Batumi Kurd activists believed their groups would be included in the program design. ${ }^{229}$ To date, the Novorossiysk Committee for Human Rights - a leading local human rights organization-Amnesty International, and Hemshin and Batumi Kurd representatives continue to appeal to the American Embassy for inclusion in the program..$^{230}$

The requirement that applicants must have fled exclusively from Uzbekistan creates similar confusion. While thc anti-Mcskhetian pogroms that took place in 1989 occurred mostly in the Uzbek section of the Fergana Valley, violence and threat of further cthnic strife caused many Meskhetian Turks (as well as Hemshins and Batumi Kurds) to flee from the Kyrgyz section of the Fergana valley and other adjacent areas in Kazakhstan. ${ }^{231}$ However, the present eligibility criteria curiously excludes those who may have fled from more "threatening" Fergana regions such as Osh and Jalalabad in Kyrgyzstan, while privileging those who left from "safer" areas in Uzbekistan such as Samarkand and Tashkent.

1t is also noteworthy that the United States rescttlement program officially classifies Krasnodar Meskhetian Turks as nationals of Uzbekistan and not Russia. ${ }^{232}$ Such a designation seems strange becausc the Meskhetian Turks fled Uzbekistan while it was still a constituent republic of the USSR and as of February 1992 became de jure citizens of the Russian Federation under the country's law on citizenship. However, as one IOM official explained, the reason behind this policy stems less from nationality law norms than from pragmatic concerns.

First, the decision followed important precedent of the U.S. Resettlement program for groups from the former Soviet Union. For

\footnotetext{
227. Id.

228. Id.

229. Interviews with IOM Official, in Krasnodar, Russ. (July 2004) (on file with author).

230. Interview with Khasan G., in Krasnodar, Russ. (Aug. 2004) (on file with author); Interview with Vadim Karatselev, Novorossiysk Committee for Human Rights, in Krasnodar, Russ. (Aug. 2004) (on file with author). For example, in the spring of 2005 , Khasan G., a representative for the Batumi Kurds (Kurmanji) joined with Hemshin leaders in writing a letter to the U.S. Ambassador to Russia requesting the opportunity to participate in the resettlement program. In their letter, the activists cited the fact that they have a similar ethnic identity to the Meskhetian Turks, were deported in 1944 and fled from Central Asia in 1989, and are now often perceived by officials and the surrounding Slavic population as Meskhetian Turks.

231. Interview with Khasan S. and unnamed Hemshin elder, Hemshin refugees from Kyrgyzstan, in Vpered, Russia (July 2004) (on file with author).

232. Id.
} 
example, the Baku Armenians, another P-2 group, were classified as refugees from Azerbaijan, even though most had fled to Russia before Azerbaijan gained its independence from the Soviet Union. ${ }^{233}$ Second, the Uzbek classification avoided much of the paperwork and the legal contortions necessary for PRM to declare the resettlement as an "in-country" processing program. This classification helped to expedite the resettlement as Uzbek nationals are subject to less extensive security checks than Russian nationals. ${ }^{234}$ Most important, perhaps, labeling the Meskhetian Turks as refugees from Uzbekistan offered a fig leaf to the Russian authorities in that it avoided making the pronouncement that Russia has manufactured a refugee crisis within its own borders. ${ }^{235}$

A more appropriate definition of eligibility would avoid the term "ethnic Turks" altogether and would include all individuals who became victims of the 1944 deportation from Southern Georgia, fled the 1989-1990 anti-Meskhetian violence in Central Asia, and are now subject to persecution by the Krasnodar authorities. Such an approach would be more consistent with the underlying goal of refugee resettlement: to alleviate the suffering of individuals whom the authorities have targeted for statelessness on the basis of their actual or perceived "Meskhetian Turkish" ethnicity.

\section{E. The Law of Unintended Consequences: A License to Persecute?}

As with considerations of who can resettle, resettlement efforts affect the development of human rights in the regions they target. No type of resettlement program exists in isolation of the root causes that precipitated the refugee crisis, which in this case is the problem of pervasive xenophobia. The case of the Meskhetian Turks demonstrates ways resettlement initiatives must integrate macro-level human rights concerns and avoid setting a problematic precedent for the future persecution of other groups. Indeed, many in the Russian human rights community, as well as in UNHCR, initially were reluctant to endorse the resettlement option believing it would (1) inadvertently intensify the problem of xenophobia in the region and (2) endanger the rights of other minorities in Krasnodar such as Hemshins, Kurds, Yezids, Armenians, Azerbaijanis, Roma, Georgians and Jews. ${ }^{236}$

The first concern was that resettlement might have the perverse effect of endorsing the actions taken by the Krasnodar authorities against the Meskhetian Turks. According to this view, resettlement would achieve the goal pursued by the authorities and extremists to rid the territory of an

\footnotetext{
233. Id.

234. Id.

235. Interview with IOM Official (Dec. 2005) (on file with author).

236. Interview with Moscow-based IOM official and with Maureen Greenwood, Amnesty International (Oct. 2005) (on file with author).
} 
"undesirable" minority. In fact, Krasnodar's nationalist governor, Alexander Tkachev, publicly welcomed the start of the resettlement and departure of the first group of families to the United States in summer 2004. In a televised speech, he declared:

We have awaited this day for a long time ...13 years ago ... the Meskhetian Turks came here for what should have been just a couple of months. From the very first days of being here they have taken advantage of free healthcare, schools, kindergartens. But staying on for too long, they never properly became part of this environment, refusing to accept our way of life. In the districts of their compact settlement, the crime rate has drastically shot up.... Now we see only one way out of this situation-for the Meskhetian Turks to leave either to Georgia or to a third country. ${ }^{237}$

This type of statement only underscores the importance of making human rights monitoring, diplomatic pressure, and support for local non-governmental organizations a part of the resettlement initiative.

If further evidence were needed, since the start of the refugee program in 2004, extremist groups and Cossack vigilantes have renewed their hate crimes and violent attacks on Meskhetian Turks with a vengeance, especially targeting those who are preparing for departure. ${ }^{238}$ ln October 2004, the Novorossiysk Committee for Human Rights publicized the appeal of one Meskhetian Turk woman for protection:

In the middle of the night men in black masks and uniforms carried out a criminal attack on our family. The men burst into the house at night and shot my husband, Islam, in the leg, causing numerous injuries with a rubber truncheon to the head, and we both received heavy concussions. These people caused our children severe moral and psychological trauma. After the incident, my youngest son Ruslan began to stutter. All of my children are now afraid to walk around outside and are afraid to spend the night at home. We are not receiving any sort of protection from law enforcement. ${ }^{239}$

In a disturbing incident two months later, a Russian man shot and killed two Meskhetian Turkish women-Narmina, age 26, and her sister Nargilya, age 19-who were his neighbors in the village of Russkoe. ${ }^{240}$ Both women had recently received notification of refugee status and were

237. Press Conference (Kuban TV July 25, 2004); Sova Center, Report on Nationalism and Xenophobia in Krasnodar Krai, available at http://xeno.sova-center.ru.

238. Union Of Councils For Jews In The Former Soviet Union, Bigotry Monitor, Vol. 5, No. 10, Mar. 11, 2005 (on file with author) [hereinafter BIGOTRY MONITOR].

239. Novorossiysk Committee for Human Rights (NCHR), Meskhetian Turks Turn in 'Werewolf' Police Officers into the Police Department, Jan. 11, 2004 (on file with author).

240. Two Meskhetian Turk Women Shot Dead in Southern Russia (BBC Worldwide Monitoring International Reports television broadcast Dec. 30, 2004), available at www.lexisnexis.com (citing REN TV, Moscow as news source); see also Novorossiysk Committee for Human Rights (NCHR), $A$ Double Murder of Meskhetian Turk Women from the Village of Russkoe in Krasnodar Krai, Dec. 12, 2004. 
awaiting departure in the next several months. Shortly before he shot his victims, the perpetrator allegedly shouted, "Why have you come here [to Krasnodar Krai] at all? All of you are visitors here! Who invited you? I'll shoot all of you! There are too many Turkish families here, and I will shoot them all!" Although the police have opened an investigation into the double murder, local prosecutors have announced that the killings were not racially motivated. ${ }^{241}$

In addition to these violent incidents, many Meskhetian Turks who have received refugee status but have not yet resettled have been prevented from selling their homes at anywhere near a fair price. Reports suggest that the regional government has unofficially ordered local banks not to honor the contracts and sale of Meskhetian Turks to outside buyers. ${ }^{242}$ Criminal gangs have targeted some of those who have sold their homes for cash. ${ }^{243}$

Another important concern in the resettlement initiative, beyond the problem of intensifying anti-Meskhetian hysteria, is to avoid sending the message that it is "open season" on other ethnic minorities in Krasnodar and in Russia as a whole. Rather than curtail the xenophobia of the regional authorities, Krasnodar Governor Tkachev has reportedly moved forward with the creation of "deportation centers" for non-Slavic migrants, announcing that the region "needs detention centers like we need air to breathe ... this kind of practice is used all over the world." ${ }^{244}$ It is extremely important that officials disabuse extremist groups of the notion that they need only do their dastardly work sufficiently loud and clear to trigger a U.S.-backed resettlement effort, which would achieve their goals of ethnic cleansing. Counteracting this pathology is of the utmost importance for protecting human rights where refugee crises are connected with racist and xenophobic ideologies. The problem is evident in a flyer this author found attached to a central building in a provincial village just outside of Krasnodar shortly after the resettlement program began in July $2004::^{245}$

\footnotetext{
241. Bigotry Monitor, supra note 238

242. Interview with Sarvar l., in Akhtyrsk, Russ. (Aug. 2004) (on file with author).

243. Memorial Human Rights Center, Monitoring of the Meskhetian turks in KRASNODAR KRAl, Dec. 2004, available at http://www.memo.ru/hr/discrim/4turk112.htm.

244. Memorial Human Rights Center, Meskhetians in Krasnodar Krai in 2005: DePORTATIONS, Feb. 2006, available at http://www.memo.ru/hr/discrim/meshi3/5krasde.htm. This report cites the experience of Bakir Gurdzhi-ogly, a Batumi Kurd, who has been denied registration since his arrival in the village of Belorechensk in 2001. Even though Gurdzhi-ogly's wife, two children, and seven siblings are all citizens of the Russian Federation, he was sentenced to expulsion in May 2004 and later placed into a deportation camp in Kopanskoi. In December 2005, migration authorities handed Gurdzhi-ogly a one-way ticket to Bishkek, Kyrgyzstan-where he has no relatives or means of support-and escorted him onto the train. Shortly after his arrival in Saratov (Russia), Gurdzhi-ogly managed to escape and has now been forced into constant hiding in Belorechensk.

245. This anonymous leaflet was found in the summer 2004 posted to a street comer in the Russian city of Krasnodar. Here it is translated by the author from Russian to English. Despite the length of the following quotation, 1 reproduce it in full because of how well it illustrates the pathology
} 


\section{Good Riddance!}

The Americans Are Getting Meskhetian Turks Out Of Russia

The story of the Meskhetian Turks in Russia is finally coming to an end! They appeared here in Krasnodar Krai between 1989-1992, as nomads from Uzbekistan. In 1992 the Russian law on citizenship took effect... thank goodness the Meskhetian Turks were not given it! On the contrary, in 2002 Governor Aleksandr Tkachev tried to implement a law on illegal migration but unfortunately, the law did not pass. Now there are 13,000 Meskhetian Turks living here. They have always stood out for their thievery, begging for handouts, and selling drugs. Now this riffraff will finally get out of Russia and will go about their normal business in the USA. By the way, one should add that the Americans aren't only bringing Meskhetian Turks home with them. At the end of last year several planes with Baku Armenians on board flew to the United States. (In 1990, after the Armenian-Azerbaijani war, the Moscow government invited these Armenians to Moscow and put them up for free in different hotels. As if there wasn't already enough trash in the capital city. However, Russian citizenship was never provided to these creatures ... . Thankfully, not all of our Russian bureaucrats can be bought by these peoples of Caucasian nationality!) .... 1t seems that in the USA they think they don't have enough Asian trash in the country. Well, let the Americans do what they want. For Russia, this decision by the US State Department can be taken as a long-awaited opportunity to get rid of Baku Armenians and Meskhetian Turks. Although they aren't taking that many people, all the same it will be easier to breathe here on Russian soil. The less dirty newcomers from the South we have in our cities, the better! Thank you so much to our American friends! From our part we would like to request that the State Department not stop with just these two small groups of trash, but to take as well all people from the Caucasus (as well as Niggers, Vietnamese, Gypsies, and Tajiks.) The poor things have a hard life in Russia. Russian "fascists" constantly persecute and sometimes even murder them in the streets! We insistently ask the Americans to be sympathetic to their plight!

This type of xenophobic reaction to resettlement may be the law of unintended consequences, promising ominously that once the Meskhetian Turks have gone, other non-Slavic minorities who stay behind will be targeted. As the flyer demonstrates, the most likely candidates for persecution are Hemshins, Batumi Kurds, Yezids, Armenians, Georgians, Azeris, and other dark-skinned ethnic groups who live in the region. ${ }^{246}$

of extremist groups and their potential reactions to the precedent being set by resettlement. (emphasis added).

246. While there is no indication that resettlement has directly spurred more violent attacks on other ethnic minorities, the program has not curtailed the incidence of vigilante groups. For example, 
This evidence of intensification of anti-Meskhetian hysteria and the targeting of other groups appropriately raises the important concern that the resettlement option should improve and promote, rather than retard, the long-term development of human rights in the Krasnodar region. Indeed, in Krasnodar as in other regions, a U.S. resettlement effort will be a truly sustainable solution only if the American government supports robust human rights programming to combat the disease of discrimination at the grassroots level. Unless the root causes of xenophobia are dealt with, perpetrators of human rights abuses will simply find new targets for their rage. To make resettlement truly a durable solution, the U.S. government must ensure that the regional authorities and Cossacks do not use the program as evidence that they have "won" the fight against non-ethnic Russians and migrants.

To apply a "human rights" approach to the resettlement effort, Washington should lead the international effort to ensure that Moscow, and in turn Krasnodar, provide Meskhetian Turks the necessary documentation, including passports, to confirm their status and be treated as full citizens. Specifically, the Russian Duma should introduce legal definitions of direct and indirect discrimination and provide for a ban on discrimination specifically in the realm of residency requirements and education. Krasnodar must also end its support for Cossack paramilitaries as a quasimilitary class and prosecute those who have committed racially motivated assaults against minorities. ${ }^{247}$ In addition, the U.S. government must support the work of local NGOs working to promote multiculturalism and a culture of human rights on the ground. ${ }^{248}$ For example, the Novorossiysk Committee for Human Rights recently completed a human rights education project, entitled "How to Defend Your Human Rights During Document Checks by Law Enforcement Organs," which trains persons of ethnic minority background in human rights law and in how to respond to police during passport checks and detentions. ${ }^{249}$ The local International Organization for Migration (IOM), the organization tasked with implementing the U.S. resettlement, must be given the capability to ensure the physical protection of the participants of the program before their departure. Finally, the right of Meskhetian Turks resident in Russia to

on December 15, 2004, skinheads attacked and brutally beat fifteen Hemshins boys at a local dance club with bats and fists, and threatened to stab them. The police came and looked at one of the boys who was badly beaten and laughed at him, asking the local Hemshin leaders not to make a fuss. E-mail from lgor K. (Dec. 2004) (citing his interview with Abdamit S. in Krasnodar) (on file with author).

247. In Russia, the incitement of cthnic and religious hatred is illegal under Article 282 of the criminal code. Ugolovnyi Kodeks RF [UK] [Criminal Code] art. 282 (Russ.).

248. Several Krasnodar-bascd NGOs are worth mentioning in this regard, such as the Center for Pontic-Caucasian Studies, the Novorossisk Committee for Human Rights, Good Deed, and Southern Wave.

249. Press Release, Novorossiysk Committce for Human Rights (NCHR), How to Dcfend Human Rights During Document Checks by the Police. How to Collectively Fight for Adherence to Human Rights Violated by Law Enforcement Agents (May 2006) (on file with author). 
return to Georgia or to respond to offers of third country resettlement should not render invalid their simultaneous right to be documented as citizens of the Russian Federation and to receive Russian passports.

These concerns that the human rights of program participants and other ethnic minorities are preserved within the targeted region are a crucial component of making resettlement a successful option for refugees.

F. The American Meskhetian Turks:

A Successful Example of U.S. Resettlement ${ }^{250}$

The perspectives of newly resettled American Meskhetian Turks are crucial and valuable evidence that resettlement is a durable solution. At the time of writing, the Meskhetian Turk community in the United States is in a state of constant growth as more individuals resettle from Krasnodar Krai to many regions across the country. ${ }^{251}$ According to data provided by the International Organization for Migration, as of mid-2006, over 10,000 Meskhetian Turks have already resettled from the Krasnodar region to the United States ${ }^{252}$ Out of approximately 21,000 applications, nearly 15,000 individuals in total will be eligible for refugee status and likely immigrate during the life of the program. ${ }^{253}$ The Meskhetian Turk resettlement program represents a departure from previous models of resettlement and placement of other refugee groups such as Cuban, Vietnamese, or Soviet Jews in that prior to 2004 no Meskhetian Turkish community existed in the United States. ${ }^{254}$ Rather than concentrate the Meskhetian Turks in one or two regions of the United States, the government has spread the population widely across the country, giving preference to communities where resettlement agencies have both the resources and the capacity to accept new arrivals. ${ }^{255}$ At the program's close, some communities will consist of hundreds of Meskhetian Turks while others will have less than ten individuals. ${ }^{256}$ To date, Meskhetian Turks have resettled to sixty-six cities and thirty-two separate states. ${ }^{257}$

Several field visits to these newly emerging communities in Philadelphia and Lancaster, Pennsylvania and San Diego, California over

250. For further discussion on the integration of Meskhetian Turks into American society, see Elisaveta Koriouchkina \& Steve Swerdlow, Meskhetian Turks in the United States, in EUROPEAN CEnter for Minority Issues (ECMI) Between INTEgration and Resettlement: The Meskhetian TURKS [hereinafter Koriuchkina and Swerdlowl (forthcoming, 2006) (on file with author).

251. Demographic data provided by the International Organization for Migration, (Jun. \& Dec. 2005) (on file with author).

252. Id.

253. Id.

254. Id.

255. Id.

256. Id.

257. Demographic data provided by the International Organization for Migration, (Jun. \& Dec. 2005) (on file with author). 
the course of 2004 and 2005 yielded evidence that Meskhetian Turks are building successful new lives despite the hardships of leaving behind everyone and everything they had known in Russia. ${ }^{258}$ These encounters provided an opportunity to record Meskhetian Turks' views on the resettlement program and to measure resettlement's success as a durable solution. The field interviews taken by the author are the earliest attempt to survey the experiences of the Meskhetian Turks in the United States using qualitative techniques. Unfortunately, due to the newness of the Meskhetian Turks' presence in the United States, there is a dearth of quantitative information about the group such as statistics on employment and educational integration. Therefore, while future studies of the population will allow for more systematic and quantitative treatment, these field interviews were an important way to gain a sense of Meskhetian Turks' experiences and reflections on their new lives. Several important themes dominated Meskhetian Turks' discussions about the experience of resettlement, such as a euphoric embrace of newfound freedom and optimism about the economic and educational opportunities available to them and their families. They stressed the crucial role local refugee resettlement agencies play in facilitating their integration into American life. While many expressed frustration about the myriad difficulties of adjusting to life in a foreign environment, most presented a picture of modest immigrant success that stands in stark contrast to the lives of discrimination and privation they left in Krasnodar Krai.

\section{Freedom from Discrimination}

Gulbakhor L. resettled from the village of Kholmskaya to the farmhouses of Lancaster, Pennsylvania with her husband and two children in July 2004. A former trader in the marketplace, Gulbakhor now works in a grocery store and spoke about the enormous sense of relief she now feels from not having to worry about the constant scrutiny of her personal identity documents by police and nationalist groups:

In Krasnodar, the biggest problem we faced was with documents.

We were afraid even to go to the store. 1 worked in Krasnodar city market and all the time officers would come by and take my documents, several times in a day even. 1t was so insulting. l'd get detained and have to have my husband's brothers come and pay a bribe to get me out of jail.259

In a telling illustration of how much the Meskhetian Turks' lives have changed, Gulbakhor related the story of how her family decided to drive from Lancaster to Philadelphia to visit her brother-in-law one weekend. "Before we got on the road, we called the woman at the refugee agency to

258. Koriuchkina and Swerdlow, supra note 250. The chapter includes a more comprehensive collection of interviews with newly resettled Meskhetian Turks.

259. Interview with Gulbakhor S., in Lancaster, Pa. (Dec. 2004) (on file with author). 
ask what kind of passport we needed to drive from Lancaster to Philadelphia. You should have heard her voice. She just laughed and said "Why would you need special documents?",260

Tiyenshon S., a cousin of Gulbakhor, also lives in Lancaster. When asked his opinion about the resettlement program, he spoke of the enormous support the community has received from the local population and resettlement agencies:

1 never expected that everything would be so positive. 1 didn't expect that I would be able to adapt so quickly. What really made a difference was the fact that so many people have helped us since we arrived here, giving us advice, and any assistance that we asked for. We didn't even have to ask. This constant smile really had a great effect on us. We were so used to people in Russia saying to us: 'why aren't you speaking the right language, or why don't you look the right way.' But here complete strangers come to our door and ask, 'what can we do for you? How can we help you?'261

\section{Earning a Livelihood}

One of the most important themes for Meskhetian Turks in their reflections on resettlement has been the opportunity to obtain employment free of discrimination. Denied registration by the Krasnodar authorities, many of those interviewed were relegated to working as agricultural laborers or petty commercial traders. Many also worried about how they would be treated when they came to the United States because the Russian media generated bizarre rumors that American government planned to use them as a slave labor force. ${ }^{262}$

Aygul S. taught geography and other subjects at a segregated school in Russia and now works at a bakery in Lancaster. In describing her experience she said:

Still it's like a dream. I can't believe 1 am here. I have been so taken aback by the upstanding nature of the people we meet, and the cleanliness and orderliness of everything. We meet good people here. We were so afraid to come. We were told that we would work as slaves and do 'black labor.'263

Aygul takes great pride in her new profession working in a local bakery. What struck her most about the United States is how few problems there are with documentation and finding work, compared to Krasnodar. She describes her encounter with her future American employer:

Honestly, we were afraid that there will be hours of questioning and waiting, but they invited us into the office immediately and

260. Id.

261. Interview with Tiyenshon S., in Lancaster, $\mathrm{Pa}$. (Dec. 2004) (on file with author).

262. Interview with Aygul S., in Lancaster, Pa. (Dec. 2004) (on file with author).

263. Id 
told us to fill out job applications. We filled them out. The man in charge asked for our Social Security numbers, made photocopies, and then said, "You're hired." They knew nothing about us. How can they hire us like that? The man said, "You can start tomorrow." 264

She said that she was amazed by that straightforward approach, and by the trust placed in her, which contrasted so greatly with the hostility and suspicion she encountered from Russian officials.

The status of being officially employed has also been a great source of pride for the Meskhetian Turks interviewed. One example is Zarema L., who now works in a packaging and mailing company in Philadelphia:

Even if it's a lesser paying job, I'd rather do that [than] get paid under the table and earn more. So many years we were used to being denied the right to work. And if we could get some type of job it was always informal. That's why it's so important to me here that I become part of the system. In our acculturation classes, we have been taught that it is key to make sure you get official documentation at work so that you can begin earning your Social Security benefits. ${ }^{265}$

This statement underlines the importance Meskhetian Turks place on becoming formal members of the workforce after fifteen years of exclusion. Interviewees' optimism about economic opportunities was tempered by the fact that many are employed in low-skilled, minimum wage jobs that often do not correspond to their level of educational in the former Soviet Union. As refugees with few savings, they are working long hours and sometimes two jobs to support their families. In San Diego for example, where most Meskhetian Turks had graduated from institutes of higher education in Uzbekistan, men have mostly taken up jobs as construction workers. Zemfira A. and other Meskhetian Turk women have taken positions as cleaning staff in some of San Diego's hotels or work as caretakers for the elderly. The hours are challenging and the pay is low, but Zemfira is hopeful. "This is just the beginning. It's a first job. 1 don't like very much that I have to work during the night time, but I am so happy that I can work and help support my family in peace."266

\footnotetext{
264. Id.

265. Interview with Zarema L., in Philadelphia, Pa. (Dec. 2004) (on file with author).

266. Interview with Zemfira A., in San Diego, Cal. (Aug. 2005) (on file with author). Life in the United States has also brought Meskhetian Turks into contact with a radically different system of social classification, and in particular the use of racial categories. When applying for jobs or filling out questionnaires or surveys, Meskhetian Turks encounter the necessity of placing themselves into one racial category. Surayo, a twenty-five-year-old woman, remarked on her experience filling out a job application: "Well, when I got to the point of indicating my race, 1 ticked off a box that said 'black.' When my boss saw it, she gasped and said, 'What are you doing? You are white, Caucasian.' I corrected my answer. But 1 was no less surprised. Back in Krasnodar, we were always referred to by the Russians as 'blacks,' and now we have turned into 'whites.' Surayo's story juxtaposes the categorization of an 'everyday racism' in Krasnodar with American racial categories. Even though the
} 


\section{A Determination to Learn}

Along with the search for economic opportunity, resettled Meskhetian Turks have brought with them the goal of educational advancement for themselves and for their children. As with the right to work, Meskhetian Turks in Krasnodar faced extraordinary obstacles in Krasnodar's educational system. Many interviewees had children who either had attended a segregated school or had otherwise faced discrimination in the educational sphere. In addition, many interviewees who had come to Krasnodar as young adults were barred from attending any institutions of higher education due to their lack of registration.

Alibek and Samet L., sons of Aybek and Zarema, are examples of how Meskhetian Turks are taking full advantage of educational opportunities available to them in their new home. ${ }^{267}$ Back in Krasnodar, the two brothers had completed their high school studies. "The kids could not wait until we went to the States because they wanted to continue on to university," said Zarema. But on their arrival, they quickly realized that without proper knowledge of English they would not be able to enter the universities they were dreaming about. With the sponsorship of the Turkish community in Philadelphia, they were sent to a college preparatory academy in Connecticut, where classes are conducted in English and partially in Turkish. In a short time, Samet and Alibek managed to catch up with their classmates. Aybek, their father, spoke proudly of his sons' determination in school. "They study 12 hours a day. Whenever we call them, they are always at a library, studying." ${ }^{.268}$ Alibek, the older of the two, has already taken the SAT for college admission and is setting his sights on attending a prestigious university such as the University of Pennsylvania. Alibek wants to become an economist, while Samet hopes to become a pilot. Aybek and Zarema hope their daughter Aynura, who now attends a public school in northeast Philadelphia, will follow her brothers' example.

\section{An Ability to Overcome Obstacles}

Job counselors at local refugee resettlement agencies emphasized that Meskhetian Turks have quickly earned a reputation in their new communities as extremely hardworking and highlighted the qualities they possess which will help their eventual integration into American society. ${ }^{269}$

\footnotetext{
Meskhetian Turks' understanding of American racial classification is largely limited, they now have a sense that they have attained a higher level of social acceptance within the construction of racial catcgories compared to their status in Krasnodar. Interview with Surayo S., in Lancaster, Pa. (Dec. 2004) (on file with author).

267. Interview with Alibek and Samet L., in Philadelphia, Pa. (Dec. 2004, May 2005, and Aug. 2005) (on file with author).

268. Interview with Aybek L., in Philadelphia, Pa. (Dec. 2004) (on file with author).

269. Nikola Krastev, U.S.: Meskhetian Families From Krasnodar Adjusting Well to Life, RFE/RL, Dec. 3, 2004, available at http://www.rferl.org/features/Default.aspx.
} 
According to Temma Klibaner, a refugee case manager for several Meskhetian families at Jewish Children and Family Services in Philadelphia, the Meskhetian Turks' history of overcoming obstacles plays a central role in this process:

When I began working with the Meskhetian Turks I was reminded of the Jews who immigrated to the United States in the 1970s and 1980s. These were individuals who, like the Meskhetians of Krasnodar, knew that there was no country for them to return to if things became difficult. Therefore, they strove even harder than all the others. In addition, like the Jews who maintained their faith underground in the Soviet period, the Meskhetian Turks have had to maintain a double life, with many identities. This trait has helped them to master several Ianguages and is making learning English easy for them. They are used to dealing with hardship and are very disciplined. These qualities will help them succeed here. ${ }^{270}$

As Klibaner's observation suggests, a history of repeated displacement, multilingualism, and struggle have made the Meskhetian Turks extremely adept at facing new obstacles, which will serve them well in their new personal and professional lives.

The positive comments about resettlement provided above are not meant to diminish the myriad obstacles faced by the Meskhetian Turks as they adjust to life in the United States. One important concern many raised was the fear that they would not be able to maintain a cohesive group identity due to the wide dispersion of their community across the United States. Accustomed to living in close quarters with large extended families and social networks back in Krasnodar, many Meskhetian Turks are battling feelings of isolation. In response to this challenge, some Meskhetian Turks are already urging a "unification" of Meskhetian Turks in one state or city. Tiyenshon S. now lives in Lancaster, and founded a lobbying and cultural organization for the Meskhetian Turks. He conveyed these concerns:

Every weekend I am out traveling all around the country visiting newly arrived families from Krasnodar. We are trying to encourage everyone to join together into one more or less unified geographic area of the country. For example, maybe we can't all get together in Pennsylvania, but at least we could be concentrated here in the northeast-New Jersey, Pennsylvania, Maryland. There are lots of families living far away in Idaho and in Oregon and Georgia. We need to bring them here so that our people remains unified. We cannot allow ourselves to disintegrate into this new society. ${ }^{271}$

270. Interview with Temma Klibaner, JCSF, in Philadelphia, Pa. (Dec. 2004) (on file with author).

271. Interview with Tiyenshon S., in Lancaster Pa. (Dec. 2004) (on file with author). 
Tiyenshon hopes his organization will eventually become a mouthpiece not only for all Meskhetian Turks living in America but also for those living in the former Soviet Union and Turkey. ${ }^{272}$

These snapshots of the American Meskhetian Turks help to demonstrate that, despite the many difficulties associated with the refugee experience, the Meskhetian Turk resettlement program has helped transform thousands of lives of persecution and constant hardship into ones of hope and opportunity. Some of the Meskhetian Turks the author interviewed in the United States for this Comment were individuals he had met earlier in Krasnodar under extremely adverse conditions. Aybek L., who had been detained and extorted by Krasnodar police and threatened by Cossack militias on a regular basis in Krasnodar, now lives in Philadelphia. He poignantly summarized the contrast between his prior and present lives:

I lived in Krasnodar for fifteen long years. 1 would go outside and get stopped and asked for my documents. The moment a police officer would see my skin color, he would become aggressive, and act as if I was a monster. But here you are protected, defended, and this makes all the difference. Here everything is available. Here if you work hard and stay within the law, everything is in your hands. But over there, nothing is in your hands. ${ }^{273}$

More than anything else, Aybek's words convey that resettlement, while not an easy experience, can dramatically improve lives. Perhaps nothing captures the essence of this newfound opportunity to live with dignity than the words of a newly resettled American Meskhetian Turk herself, who said:

Our lives have changed radically in the sense that we have begun to live without the constant fear and disturbances of life in Krasnodar. There we always lived in fear that maybe they'd kick us out that day, maybe the next day, or the day after that. Fifteen years we lived in that condition. But here I have the same rights as the President of the United States.... Here in America I am finally a free person..$^{274}$

In the context of a Soviet legacy of deportation and persecution in Georgia, Uzbekistan, and Russia, resettlement appears to be the most durable solution for the Meskhetian Turks.

\section{CONCLUSION}

The Meskhetian Turks' search for durable solutions has reverberations far beyond the borders of Southern Russia and Georgia. An understanding of their story provides insight into more general strategies for protecting minority rights in post-Soviet space and effectively using the

272. Id.

273. Interview with Aybek L., in Philadelphia, Pa. (Dec. 2004) (on file with author).

274. Interview with Gulbakhor S., in Lancaster, Pa. (Dec. 2005) (on file with author). 
tool of refugee resettlement in the United States. The persistent ethnic discrimination against this vulnerable minority group not only spurs the growth of racism and xenophobia in Russia, but also may spread to other areas of the former Soviet Union as a model of what to do with "undesirable" groups. The lessons of Krasnodar also reveal the contours of ethnic discrimination in the Russian Federation today-a combination of dysfunctional federalism, bureaucratic inertia, and reactionary nationalism. Integration of the Meskhetian Turks into Krasnodar at present is clearly an impossible goal.

Likewise, the Republic of Georgia continues to hinder the process of repatriation by failing to enact adequate legislation that would promote the human security of Meskhetian Turk repatriates while acknowledging their freedom to their own culturally distinct identity. As long as the Georgian government continues to violate its obligations under the framework established by the Council of Europe, repatriation seems an unlikely solution. The international community should continue to pressure the new president, Mikheil Saakashvili, to live up to the democratic aspirations goals his government announced shortly after Georgia's 2003 Rose Revolution.

It is in these dire circumstances for the Meskhetian Turks, nearly sixty years from the date of Stalin's deportation of the Meskhetian Turks, that the U.S. resettlement effort appears the most effective way to provide a permanent remedy to those who have suffered for so long. However, as we have seen, the United States government must be cautious not to send the wrong message to Krasnodar. In the short run, to avoid creating a damaging precedent, the United States must insist that Russia live up to its human rights obligations by granting citizenship to stateless persons and cracking down on Cossacks. In the long run, it must support the efforts of local NGOs to fight racism and xenophobia with education, human rights monitoring, and legal support.

In the meantime, those Meskhetian Turks who make the United States their new home are a living testament to the U.S. refugee resettlement program's potential to provide hope, brighter futures, and better lives. Moreover, the story of the Meskhetian Turks' triumph in the United States underlines the overall success and overwhelming potential of the U.S. overseas refugee program as both a domestic and foreign policy tool. Especially in the post-September 1 I context, it is crucially important to call attention to the case of the Meskhetian Turks as an example of U.S. support for a persecuted minority as well as a Muslim population. Continuing to promote durable solutions and utilize resettlement for groups such as the Meskhetian Turks will help ensure the United States remains a leader in humanitarian affairs and human rights. 